\title{
EL DESTINO DE LOS TEMPLOS PAGANOS EN HISPANIA DURANTE LA ANTIGÜEDAD TARDÍA
}

\author{
POR \\ JORGE LÓPEZ QUIROGA ${ }^{1}$ y ARTEMIO M. MARTÍNEZ TEJERA ${ }^{2}$ \\ Universidad Autónoma de Madrid
}

\section{RESUMEN}

El destino de los templos paganos en Hispania durante la tardo-antigüedad constituye un fenómeno complejo que, a partir de la ambigua información textual y de las todavía escasas evidencias materiales, se manifiesta mucho más tardíamente y de forma menos generalizada respecto a otros ámbitos occidentales y orientales. No se constata una política sistemática y programada de destrucción o desmantelamiento de templos paganos por parte de las autoridades religiosas cristianas en Hispania. Un factor importante ha sido el lento progreso de la cristianización en el medio rural para determinadas áreas de la Península y otro, síntoma y consecuencia de lo anterior, el mantenimiento de prácticas y espacios cultuales paganos tanto en la ciudad como en el campo.

\section{SUMMARY}

The destiny of the pagan temples in Hispania during the Late Antiquity constitutes a complex phenomenon that, from the ambiguous textual information and still the little material evidences, is less generalized with respect to other Western and Eastern areas. A systematic and programmed policy of destruction or dismantling of pagan temples through Christian religious authorities in Hispania is not stated. An important factor has been the slow progress of christianity for certain rural areas of the Iberian Peninsula and the maintenance of pagan practices and pagan spaces as much in the city as in the countryside.

PALABRAS CLAVE: Templos paganos, Antigüedad Tardía, Península Ibérica, Cristianización.

KEY WORDS: Pagan temples, Late Antiquity, Iberian Peninsula, Christianity.

1 Departamento de Prehistoria y Arqueología. Facultad de Filosofía y Letras. Universidad Autónoma de Madrid (UAM). Este artículo se enmarca en el proyecto de investigación Estudio analítico de los asentamiento rurales tardo-romanos en 'Hispania' (siglos IV-VII): una propuesta de trabajo interdisciplinar, financiado por la Universidad Autónoma de Madrid (investigador principal: Jorge López Quiroga), formando parte de la línea de investigación que venimos desarrollando dentro del Programa "Ramón y Cajal" financiado por el Ministerio de Educación y Ciencia (fondos FEDER de la U. E.).

2 Dr. en Historia del Arte. Universidad Autónoma de Madrid (UAM).

3 En el s. IV el término "templo" se utilizará para designar los espacios sagrados paganos (canon I del concilio de Elvira), siendo a partir del s. VI cuando tiene lugar su cristianización ("templum Christi" o "templum Dei"), tal y como ocurrirá con el término 'basílica': Martínez Tejera 2004 inédito: T. III, 23-24.

\section{INTRODUCCIÓN}

En un estudio reciente sobre el siglo V en Hispania se ha afirmado que el proceso que condujo a la cristianización de los templos ${ }^{3}$ paganos "no ha sido suficientemente estudiado para el caso de Hispania" y que estos templos "o se desmontan, o se reocupan, o se dejan caer en el olvido" (Arce 2005, 29 y 247) ${ }^{4}$. Y la principal causa de nuestro desconocimiento se debería, sin duda, a la exigua documentación conocida sobre dicho proceso en la Península Ibérica para los siglos de la Tardo Antigüedad $(\text { siglos IV-VII })^{5}$ : al día de hoy no se conocen - para la Península Ibérica y a lo largo de dicho periodo - referencias literarias y/o arqueológicas relativas a "templos paganos" convertidos o transformados en "templos cristianos" "

4 Queremos dejar constancia de la publicación de varias obras que tal vez puedan ser relevantes para el tema a tratar pero que fueron publicadas con posterioridad a la redacción original del texto aquí publicado: C. Sotinel, "Les lieux de culte chrétiens et le sacré dans l'Antiquité tradive", RHR 222, 2005, 411-434 y J. Hahn, From Temple to Church: Destruction and Renewal of Local Cultic Topography in Late Antiquity. Religions in the Graeco-Roman World. Leiden 2006 (in Druckvorbereitung) (mit Stephen Emmel, Ulrich Gotter). Y recordar también una obra que no hemos podido localizar: J. Hahn, Tempelzerstörung und Tempelreinigung, en R. Albertz (Hrsg.), Kult, Konflikt, Sühne. Veröffentlichungen des Arbeitskreises zur Erforschung der Religionsund Kulturgeschichte des Antiken Vorderen Orients, Band 2. Münster 2000, 269-285.

5 Sanz Serrano 1995, 238

6 Una carencia y problemática ya señalada con anterioridad: "nada sabemos de las actuaciones concretas, de la topografía de las destrucciones, de los personajes implicados o de la problemática de los enfrentamientos y sólo nos queda la posibilidad de encontrar su plasmación real en las destrucciones de templos paganos atestiguadas por la arqueología [...] Si abandonamos este tipo de fuentes - se refiere a las textuales -, encontramos la misma complejidad en aquellas pertenecientes al ámbito de la arqueología o del arte en general [...] nos encontramos con la imposibilidad de datar con precisión restos arqueológicos por la superposición de construcciones a lo largo de siglos y por la carencia de excavaciones sistemáticas tanto en las ciudades como en el campo [...] Una de las problemáticas más importante es aquella que relaciona los documentos arqueológicos con las relaciones paganismo-cristianismo. En este sentido la situación es sumamente compleja": Ibidem, 240, 242 y 245. 
los templos paganos. Pero no es menos cierto que frente a tan significativo silentium destaca el papel desempeñado por las ecclesia como espacios de refugio y asilo $^{7}$, un derecho, el de asilo, "que conferían las estatuas de los emperadores cuya protección, por lógica, fue trasladada a las iglesias" (Sanz Serrano 2003, 49). ¿Significa esto que ya en el siglo IV la práctica del paganismo había desaparecido en Hispania? Obviamente no.

Resulta evidente que durante el siglo IV el paganismo aún pervivía en el Imperio y por supuesto en la península, y tanto en el mundo rural ${ }^{8}$ como en el urbano ${ }^{9}$; y con la religión, también perduraron, lógicamente, sus espacios de culto, sus templos y santuarios (Sanz Serrano 2003). Las primeras manifestaciones de la pervivencia de templos paganos ('templum idoli') las encontra-

\footnotetext{
7 Al menos desde la primera mitad del siglo VI en Mérida, ya que según el texto de las Vitas Sanctorum Patrum Emeritensium (de ahora en adelante, VSPE), a este privilegio, el del asilo y refugio, fue al que se acogió Vagrila, seguidor emeritense del obispo arriano Sunna, que junto con su mujer e hijos pidió asilo en la basílica de Santa Eulalia ("ad basilicam sanctae Eulaliae ab remedium percipiendum confugivit...”). Más tarde Recaredo ordenó que todos ellos, junto con su patrimonio, vivieran allí como servi de la virgen Eulalia. VSPE: 74 y 116. Una excepción fue la irregular decisión (así la calificó Gregorio Magno) adoptada - en torno al 603 - por el enviado imperial a Hispania, el bizantino Comenciolo, contra el obispo malacitano Genaro, al que expulsó de la iglesia en la que, haciendo efectivo el derecho legal de asilo que le amparaba, se había refugiado: Registrum...: 13, 49 y 20-26. Y ya en tiempos de Ervigio, el canon décimo del XII Concilio de Toledo (681) permitirá a los que se refugian en la iglesia moverse libremente dentro de la misma y en una distancia de treinta pasos a contar desde las puertas de la misma ("ut nullus audeat confugientes ad ecclesiam vel residents inde abstraere..., sed esse potius his ipsis qui ecclesiam petunt per omnia licitum in triginta passibus ab ecclesiae ianuis progredi, in quibus triginta passibus uniuscuiusque ecclesiae in toto circuiti reverentia defendetur..."): Vives - Marín - Martínez 1963 (de ahora en adelante, CVH): 397-398: "De aquellos que se refugian en la iglesia. Puertas 1975 (de aquí en adelante, IH): 116. Martínez Tejera 1993: 171-173 y 2004, inédito: T. II, 161, nota n ${ }^{\circ} 708$. Bango 1997: 67.

8 "Ya en el mundo pagano existió una estrecha relación entre los templos y el ámbito rural pues en el 386 Libiano escribió a Teodosio para protestar contra la sistemática destrucción de templos paganos por parte de los cristianos, recordándole además la importancia que estos tenían para la fertilidad de los campos, para la agricultura en general...": Martínez Tejera 2004, inédito: T. III, 23-24.

9 Para comprender la transformación de la topografía de los espacios urbanos hispanos en la Antigüedad Tardía son fundamentales los estudios de García Moreno 1977-1978; Barral 1982; Gurt, Ripoll - Godoy 1994; Gurt 1995, 2001 y 2004; López Quiroga, 2004; López Quiroga -Rodríguez Lovelle 1998; Arce 2003; Fernández Ochoa - Morillo Cerdán - López Quiroga 2005.
}

mos en las actas del llamado "Concilio de Elvira" (¿a.306-396? $)^{10}$, uno de los primeros concilios provinciales, si no el primero, celebrado en Hispania después de que Constantino pusiese fin (el 25 de julio del 306) a la persecución iniciada por Diocleciano contra los cristianos de la Galia, Britania e Hispania tres años antes, el 23 de febrero del $303^{11}$; sus actas, ya desde su primer canon, reflejan una honda preocupación por la pervivencia de la idolatría entre los cristianos y por la difusión del paganismo y de sus ritos ${ }^{12}$, preocupación que coincidirá con la "fase de oficialización" del Cristianismo a finales del s. $\mathrm{IV}^{13}$. Una difusión del paganismo que en ocasiones se mostró imparable, como muestra el canon XLI ('Ut prohibeant domini idola colere servis suis' $)^{14}$. Tan imparable como lo fue la violenta reacción de algunos cristianos que se dedicaron a destruir los ídolos y que, en algunos casos, murieron en el intento sin alcanzar por ello la corona del martirio ${ }^{15}$.

Los cánones antipaganos del concilio de Elvira arremeten contra toda una serie de prácticas o costumbres asimiladas por una cristiandad hispana todavía un tanto titu-

${ }^{10}$ Para Suberbiola 1987, en realidad se trata de los cánones XII y XIII del Concilio de la Lusitania (396). Personalmente pensamos que sus disposiciones encajan más con el antipaganismo de finales del siglo IV, consecuencia de la oficialidad del Cristianismo, que con el momento que vivía la religión cristiana con anterioridad al "edicto de Constantino" a principios de ese siglo. Diferente opinión sobre la cronología del concilio mantiene Ramos-Lisson 2005, 70 y ss.

${ }^{11}$ Una persecución que supuso, para la primera arquitectura cristiana, un duro revés, pues ordenaba la destrucción de las iglesias y de las casas en las que se encontrasen copias de las escrituras. Y Constancio Cloro, César en Occidente, sí permitió la destrucción de los lugares de reunión de los cristianos: Arce 1993: 9.

${ }^{12}$ C.I. De his qui post babtistum idolis imolaverunt. C.II. De sacerdotibus gentilium qui post babtismun immolaverunt. C. III. De eis[dem] si idolis munus tantum dederunt. C. IV. De eisdem si cathecumini adhuc immolant quando babtidientur. Difusión del paganismo que intentan evitar al prohibir a las cristianas contraer matrimonio con los gentiles e infieles y la presencia de ídolos en las casas: C. XV. De coniugio forum qui ex gentilitate veniunt. C. XVI. De puellis fidelibus ne infidelibus coniungantur. C. XVII De his qui filias suas sacerdotibus gentilium coniungunt; C. XLI. Ut prohibeant domini idola colere servis suis. En cuanto a la pervivencia de rituales y sacrificios de origen pagano, esta se pone de manifiesto en los cánones XXXIV (Ne cerei in cimiteriis incendantur), XXXV (Ne feminae in cimiteriis pervigilent) y LIX (De fidelibus, ne ad Capitolium causa sacrificando ascendant): CVH: 1-2, 4-7 y 12.

${ }^{13}$ Teja 1993: 14 y ss. Sobre la repercusión arquitectónica de esta fase en Hispania: Martínez Tejera 2005.

${ }^{14}$ CVH: 8-9. Sanz Serrano 1995, 240.

15 Ibidem, 12: C. LX. De his qui destruentes idola occidentur. Sanz Serrano 1995, 239, nota $\mathrm{n}^{\circ} 4$. 
beante en sus costumbres. Pero estos titubeo s no sólo afectaron a la cristiandad del siglo IV; un siglo después todavía observamos una situación muy similar en la Gallaecia ya que dos capítulos orientales de los recogidos en las actas del II concilio de Braga (572) seguirán reiterando la inconveniencia de llevar alimentos a los sepulcros de los difuntos ("ac defunctorum sepulchra") y de celebrar misas sobre los monumentos ("ad monumenta"), es decir, en los cementerios ${ }^{16}$. Que el paganismo seguía vivo en la Gallaecia del tercer cuarto del siglo V lo demuestra el hecho de que tres de esos capítulos orientales recogidos en las actas del segundo concilio bracarense informen de la pervivencia de actividades paganas entre los cristianos ${ }^{17}$. Y decimos reiteran porque esta ya fue una problemática puesta de manifiesto unos años antes, en el canon 23 del segundo concilio de Tours (567), en el que los asistentes se lamentaban de que muchos fieles acudiesen, en la festividad de San Pedro, primero a la ceremonia sagrada y después a ofrecer alimentos a los muertos ("sacrificia mortuorium"); una costumbre que ha pervivido en la exposición de alimentos para difuntos que actualmente se realiza el 18 de febrero (Martínez 2004: T. III, 85).

Y el mismo panorama nos revela para el ámbito rural $^{18}$ la pluma del panonio San Martín de Dumio (ya como obispo de Braga), al que debemos la homilía De correctione rusticorum (circa 574) ${ }^{19}$; este sermón - sin

${ }^{16}$ C. LXVIII. [De eo quod non liceat super monumenta mortuorum missa tenere] y C. LIX. [De eo quod non liceat christianis parandia ad monumenta portare]): CVH: 102. "No cabe duda de que en el caso de los rituales llevado a cabo en los cementerios se trata de la cristianización de las feralia o parentalia, de las fiestas paganas en honor de los muertos que tenían lugar en el mes de febrero y durante las cuales el pueblo acudía a los cementerios a conmemorar a sus difuntos (conmemoración, también conocida como cara cognatio, que transcendiendo al primer cristianismo fue rechazada enérgicamente por San Agustín en su tratado De moribus ecclesia catholicae...": Martínez Tejera 2004, inédito: T. III, 85.

${ }^{17}$ Concretamente los $\mathrm{n}^{\circ}$ LXXI ([De eo quo non liceat christianis obsecrationes diversas adtendere ]), LXXII ([De eo quod non liceat christianis tenere tradiciones gentilium et observare lunae aut stellarum cursus]) y LXXIII ([De eo quod non liceat kalendas observare]): $\mathrm{CVH}, 103$.

${ }^{18}$ Utilizamos "rural" en vez de "campo" atendiendo a la diferenciación señalada por Caseau 2004, 106, ya que el término "campo" no es el más apropiado cuando de lo que se trata es de la localización de los templos no urbanos: recordemos que las "ciudades" estaban formadas por un centro urbano y por un territorio y que en este último se incluía una zona suburbana y habitada en la que nos podemos encontrar templi (en su mayoría privados) y villae, la del ager, y otra no cultivada, el saltus, bosques y montañas, en ocasiones salpicados de santuarios. Los templos rurales (fana) en su mayoría generaron áreas sagradas menores, a lo sumo provistas de un altar o un ara votiva y delimitadas, cercadas.

${ }^{19}$ Obra editada por Maciel 1980 y Del Val 1990, entre otros. duda influenciado por San Agustín (De catechizandis rudibus) - fue dirigida a Polimius, obispo de Astorga, con el fin de que aplicase convenientemente en su diócesis - y en las 10 parroquias que, según el Parroquial Suevo, la componían - lo establecido en el II concilio provincial de Braga (572) respecto a la "corrección" y justo enderezamiento de las costumbres priscilianistas y paganizantes imperantes entre los rustici cristianos (los habitantes del "campo") desde los tiempos del obispo Dictinus ${ }^{20}$. Su testimonio corrobora la vitalidad del culto pagano en las áreas sagradas rurales (en los fana o sacella) ${ }^{21}$, construidas para tal efecto en ríos, altos montes y bosques frondosos, y pone de manifiesto muchos de los rituales paganos que se llevaban a efecto entonces en el mundo rural por parte de los rustici cristianos $^{22}$. Los templos rurales, durante el siglo $\mathrm{V}$, fueron parte destacada de la dinámica social.

Que el paganismo era una realidad muy extendida en la península ibérica incluso en el último cuarto del

20 "Epistolam tuae sanctae caritatis accepi, in qua scribis ad me ut pro castigatione rusticorum, qui adhuc pristina paganorum superstitione detenti cultum venerationis plus daemoniis quam deo persolvunt, aliqua de origine idolorum et sceleribus ipsorum vel pauca de multis ad te scripta dirigerem...": De Correctione..., 1. En cierto sentido su trascendencia en el monacato del noroeste peninsular es muy similar a la que representó Martín de Tours en la Galia, verdadero difusor entre los "rústicos"del Cristianismo y de una áscesis monástica de raíz oriental.

${ }^{21}$ Para otras zonas de la parte oriental del Imperio: Augier 1999.

${ }^{22}$ De Correctione..., 8: "ut in excelsis montibus et in silvis frondosis sacrificia sibi offerrent et ipsos colerent pro deo...". De Correctione..., 9: "Suaserunt etiam illis daemones ut templa illis facerent et imagines vel statuas sceleratorum hominum ibi ponerent et aras illis constituerent, in quibus non solum animalium sed etiam hominum sanguinem illis funderent. Praeter haec autem multi daemones ex illis qui de caelo expulsi sunt aut in mare aut in fluminibus aut in fontibus aut in silvis praesident, quos similiter homines ignorantes deum quasi deos colunt et sacrificant illis. Et in mare quidem Neptunum appellant, in fluminibus Lamias, in fontibus Nymphas, in silvis Dianas ...". De Correctione..., 16: "Nam ad petras et ad arbores et ad fontes et per trivia cereolos incendere, quid est aliud nisi cultura diaboli? Divinationes et auguria et dies idolorum observare, quid est aliud nisi cultura diaboli? Vulcanalia et Kalendas observare, mensas ornare, et lauros ponere, et pedem observare, et fundere in foco super truncum frugem et vinum, et panem in fontem mittere, quid est aliud nisi cultura diaboli? Mulieres in tela sua Minervam nominare et Veneris diem in nuptias observare et quo die in via exeatur adtendere, quid est aliud nisi cultura diaboli? Incantare herbas ad maleficia et invocare nomina daemonum incantando, quid est aliud nisi cultura diaboli? Et alia multa quae longum est dicere...". 
siglo VI se constata en el texto del canon XVI del III Concilio de Toledo (589), que dispone que "los obispos en unión de los jueces destruyan los ídolos, y que los señores prohíban a sus siervos la idolatría. Por estar muy arraigado en casi toda España y la Galia el sacrilegio de la idolatría, con el consentimiento del gloriosísimo rey..." ${ }^{23}$. La monarquía, el rey, y la Iglesia, el obispo, serán los encargados en la Hispania de finales del siglo VI de "investigar" y "actuar" en todo lo relacionado con el paganismo. Una política que se mantendrá en el siglo VII, especialmente por parte de la iglesia como se deduce del canon XI del XII concilio de Toledo (681), "De los adoradores de ídolos", y en el II del XVI concilio de Toledo (693) dirigidos no solo a los "adoradores de ídolos" sino también a los que veneran las piedras, los que encienden antorchas, y adoran las fuentes y los árboles..." (CVH: 398-399 y 498-500. Sanz Serrano 1995, 239, nota $\left.{ }^{\circ} 4,240,241\right)$. En la zona más agreste del "campo" muchos emplazamientos naturales (lagos, ríos, cuevas, bosques, cumbres, etc.) fueron sacralizados, entregados a las divinidades, por tratarse de espacios de gran belleza o bien por tener unas condiciones especiales o extraordinarias (thaumaston); en cualquier caso, no prevaleció un único modelo para su localización (Percial 1976). Era en estos santuarios y en los del territoria donde los campesinos, agradecidos a las deidades por las buenas cosechas, ofrecían los primeros frutos recolectados, flores e incienso (De Cazanove 2000, Caseau 2004: 108-109).

Será a partir del siglo IV cuando se inicie un proceso de transformación topográfica político-religiosa de la ciudad en el que el templo pagano será sustituido progresivamente por el templo cristiano, o al menos parcialmente pues Plinio hacía ya mucho tiempo que distinguió entre el templo, "para los dioses" y sus pórticos, "para los hombres" ${ }^{24}$. Pero transformación no tiene por qué significar degradación o ruina; que la ciudad tardo-antigua sea distinta, desde la perspectiva urbanística, a la romana, no significa que sea una ciudad "decadente" o una ciudad en ruinas (Brown 1978: 29). En la tardo-Antigüedad hispana - como en el resto de las provincias del Imperio - el urbanismo evolucionará de manera distinta a como lo venía haciendo pero,

\footnotetext{
${ }^{23}$ CVH: 129-130. Sanz Serrano 1995, 239, nota $n^{\circ} 4$. Una de estas costumbres paganas arraigadas fue la de bailar en las fiestas natalicias de los santos (ibidem, 133, C. XXIII. Ut in sanctorum natalitiis ballemacieae prohibeantur). Un ejemplo galo lo encontramos en el concilio de Narbona (589), canon XV, que condena las prácticas paganas entre los cristianos: CVH, 150.

${ }^{24}$ Caseau 2004, 107. Conviene no olvidar esta sutil diferenciación cuando se hable de la construcción de una ecclesia en un antiguo templum pagano: ¿se construirá en el área sagrada del templo o solo en sus pórticos?
}

y esto es lo importante, evolucionó. Aunque a partir del siglo IV dejará de funcionar como institución, la ciudad tardo-antigua es una ciudad viva, aunque un poco "retraída", en la que perduran las grandes áreas sagradas urbanas monumentalizadas y adornadas con templos, ninfeos, etc.; en el siglo IV la civitas seguirá siendo el "hábitat de los ciudadanos", una res publica, y como tal se seguirán construyendo y restaurando sus templos con fondos públicos, aunque en mucha menor medida que en tiempos precedentes. Lo que cambiará con respecto a la ciudad romana será su relación con el poder y con la sociedad que la habita ${ }^{25}$; el cambio de modelo. $Y$ en este proceso de transformación del tejido urbano la Iglesia, el Cristianismo, con su nueva ideología, desempeñó un papel fundamental. ¿Podía permitirse el todavía incipiente Cristianismo hispano, especialmente durante los siglos IV-V, el más leve atisbo de relación con el mundo pagano? Todo parece indicar que no.

En un reciente artículo, Ward-Perkins afirmaba que la mayor parte de los templos adaptados como iglesias en la parte occidental del Imperio sufrieron dicha trasformación a partir del siglo quinto ${ }^{26}$. ¿Ocurriría así en Hispania? Como tendremos ocasión de comprobar resulta muy difícil llegar a conclusiones definitivas respecto a por qué fueron adaptados al uso cristiano algunos templos (y solamente algunos de ellos). Por lo general los espacios religiosos paganos siguieron "suertes" muy diversas; unos fueron "secularizados" y convertidos en espacios profanos y en objetos decorativos, de "embellecimiento"; otros fueron, simplemente, destruidos y algunos, los menos, fueron "reconvertidos" en espacios religiosos cristianos ${ }^{27}$. Estos últimos serán los que acaparen nuestra atención, independientemente de que se encuentren en el mundo rural (suburbio, villa, ager, saltus, etc), o en el urbano (urbs, ciuitas, domus, etc).

\footnotetext{
${ }^{25}$ Gracias al régimen municipal romano, imperante hasta entonces, la ciudad se asomaba a la Antigüedad Tardía como una unidad política que disfrutaba de un alto grado de soberanía y de autonomía frente al estado supraterritorial, asumiendo "diversos compromisos solidarios, a través del sistema de coordinación provincial (concilium provinciae), en cuanto a censos, tributos, levas, comunicaciones, paz social, dominio de la ley, etc. Sin conformar el imperio de las ciudades, sí fue el romano un Imperio de ciudades...": Urbano 1997, 39.

${ }^{26}$ 2003, 290 ("Most of this cases of temples adapted into churches cannot be dated whith any precision, but there are indications that at least some of these transformations took place in the fifth century, in other words long before the phenomenon is documentated in the west...").

${ }^{27}$ Desacralización de los templos y objetos religiosos paganos - estatuas, etc. - durante la Antigüedad Tardía que ha sido objeto de análisis por Caseau 2001.
} 
A la hora de conocer el destino de los templos paganos en la Antigüedad Tardía no solo ha de tenerse en cuenta su diversidad (urbano o rural), también sus diferencias en cuanto a su status legal, notables e importantes para la cuestión que nos ocupa (Caseau 2004: 110 y ss.). De acuerdo a esta premisa los templos y recintos o espacios sagrados pueden dividirse, grosso modo, en los consagrados por el emperador (o en su nombre) o bien - y estos fueron la inmensa mayoría los pertenecientes a la ciudad o a una determinada familia. En definitiva, en templos públicos y en templos privados. Se trata de una diferenciación que en el plano jurídico conlleva sustanciales diferencias, pues las consecuencias de su "desacralización" no serán las mismas en uno que en otro caso: mientras que los templos públicos eran inviolables e inalienables y su destrucción suponía un sacrilegio (el emperador era, como pontifex maximus, el único que podía decidir sobre su destino), los templos privados administrados por la curia o bien por ciudadanos no tenían la condición jurídica de "lugares sagrados": podían construirse sin previa autorización imperial y podían ser legalmente demolidos o "desacralizados" sin la intervención de las autoridades ${ }^{28}$.

Esto significa que fueron muy pocos los templos considerados sagrados desde un punto de vista legal; la mayoría tuvieron un status de edificio religioso privado, especialmente los rurales, entre los que se encontraban los situados en las villae. Algunas tuvieron su propio espacio, su propio templo, en el que practicar un culto privado y doméstico: se trata del lavarium, en ocasiones también conocido como sacrarium (Orr 1978. Baker 1994). Tras la clausura de los templos rurales los santuarios privados de las villae, que seguirán en funcionamiento hasta bien entrado el siglo $\mathrm{V}$, se convirtieron en el único refugio del paganismo pues en el ámbito de lo privado los Edictos Imperiales tuvieron un menor efecto, una menor repercusión.

\section{LA DESTRUCCIÓN DE TEMPLOS PAGANOS}

\subsection{EN EL IMPERIUM}

En su Vita Constantini, Eusebio, obispo de Cesarea, afirma que el emperador promulgó un edicto en el en el otoño del año 324 por el que prohibía las prácticas asociadas al paganismo en todo el Imperio: adorar a los ídolos, hacer sacrificios a los dioses, encargar oráculos, erigir simulacros y celebrar ritos ocultos se convertían en

\footnotetext{
${ }^{28}$ Categoría en la que se incluían todos los templos consagrados fuera de Italia: ibidem.
}

actividades prohibidas ${ }^{29}$. Incluso San Jerónimo y Paulo Orosio llegaron a señalar que Constantino I había publicado otro edicto por el que ordenaba la destrucción de los edificios de culto pagano ${ }^{30}$. A priori parece poco probable, aunque no imposible, que fuera así ya que, en primer lugar, resulta cuando menos sospechoso que una disposición de tanto alcance no aparezca recogida en una compilación legislativa de tan gran trascendencia como el Codex Theodosianus, una compilación legislativa que solo recogerá medidas similares a partir del año $341^{31}$; lo que si es cierto es que sus Constitutiones ofrecen el soporte o marco legal que permitirá tal proceso en todos y cada uno de los rincones del Imperio, aunque se sospeche que algunas de ellas no fueran sino un "rescriptum motivado por la occasio legis", es decir, que junto a las legis generalis podremos encontrar disposiciones motivadas por casos muy concretos (Buenacasa 1997-1998, 27). Y, en segundo lugar, que el texto continua diciendo que mandó a las iglesias "que aumentaran las dimensiones de los templos en altura, anchura y longitud..." 32 , lo que significa que ambos espacios, los paganos y los cristianos, convivían pero no se superponían ${ }^{33}$.

${ }^{29}$ Vita Constantini, Libro II, 22 y ss. (236-237): “a los que daban muestras de secundar el paganismo les prohibió sacrificar a los ídolos [...] puso veto a los abominables ritos de la antigua idolatría [...] nadie podía osar erigir estatuas, ni emplearse en oráculos ni similares artes, ni, por supuesto, celebrar sacrificio alguno...".

${ }^{30}$ El primero en su Chronica (331) y el segundo en su "Historia contra los Paganos" (Historia adversus paganus, VII, 28,28).

${ }^{31} \mathrm{Si}$ bien es verdad que al tratarse de escritos dirigidos a funcionarios no tenían por qué aparecer en una recopilación como el Codex Theodosianus (Vita Constantini, 237, nota ${ }^{\circ}$ 63). Que Constantino no intentó alterar el culto tradicional lo indica el hecho de que siguiera considerándose pontifex maximus y lo demuestra los testimonios de autores no cristianos recogidos por Buenacasa 1997-1998, 29, nota $n^{\circ} 10$. Constantino I "tan solo priorizó una religión, pero sin llegar a prohibir las demás" (ibidem, 29). Medidas recogidas posteriormente por Arce 2005, 246 y ss. Lo que no impide que en casos muy concretos actuara de manera contundente, como pudo ocurrir con la iglesia del Santo Sepulcro de Jerusalén; según el testimonio de Eusebio de Cesarea (Vita Constantini Libro III, 25-27, 288 y ss.), sobre la tumba de Cristo los paganos construyeron un templo dedicado a Afrodita. Constantino, "el amigo del Dios Universal", mando arrasar el edificio, excavó hasta que "estrato tras estrato" llegó a la tumba y erigió sobre ella un oratorio, en realidad el más importante de los "Martirya".

32 Vita Constantini, Libro II, 45, 237.

${ }^{33}$ No hay duda del funcionamiento de los templos paganos durante su reinado pues así lo certifican los relatos de distintos autores, tanto no cristianos (Libanio y Juliano) como cristianos (Eusebio de Cesarea), recogidos por Buenacasa 1997-1998, 29, notas $\mathrm{n}^{\mathrm{os}} 10$ y 11 y Caseau 2001, 86 y ss. 
No obstante sí hay constancia de la destrucción de algunos santuarios paganos por orden de Constantino "el Grande", el primer "arqueólogo" de la Historia, aunque ninguno en Hispania $^{34}$, ni siquiera en Occidente, sino en Oriente ${ }^{35}$. La clausura de los templos urbanos (la prohibición de acceder a ellos), pero no de los rurales ${ }^{36}$, así como la prohibición de celebrar ceremonias paganas serán medidas recogidas por varias "constituciones" imperiales de Constante I (337-350) y Constancio II (337-361), lo que significa su vigencia tanto en la parte occidental como en la oriental del Imperio ${ }^{37}$. Una legislación que amparará la destrucción de templos paganos por parte de algunos obispos en diversos territoria imperiales a lo largo del siglo IV como consecuencia de las decisiones adoptadas por Teodosio el 8 de noviembre de 391 (prohibir las ceremonias paganas en todo el Imperio) y por Arcadio el 10 de julio de 399 (ordenar la destrucción de los templos que se encuentran en los campos, pero sin tumultos) ${ }^{38}$, lo que dio paso a un progresivo

34 Vita Constantini, Libro III, 26-29, 51-53, 55-56 y 58. BUENACASA 1997-1998, 30-31. Además de en Jerusalén, en Afaca y Heliópolis (Phoenice), Aigai (Cilicia), Antioquía y en Mambré, estas últimas arrasadas para la construcción de los edificios cristianos planificados por él. Una actividad constructiva que le llevó a ser considerado por la sociedad de su tiempo - y sobre todo por la desarrollada en Constantinopla y en África del Norte- como un activo transformador de santuarios paganos en iglesias cristianas: Lepelley 1979, 345-346.

${ }^{35}$ Cuando en el 312 Constantino emprendió obras en la ciudad más sagrada del Imperio occidental, en Roma, todas las nuevas iglesias se alzaron sobre espacios que carecían de una trascendencia religiosa previa, como la basílica de Leterano, o bien sobre santuarios dedicados a los mártires, como ocurrió con San Pedro. Aunque ningún texto permite justificar con certeza su actitud, esta actuación - tan distinta a la desarrollada en Jerusalén, en una ciudad del Imperio oriental - parece deberse a su deseo de no herir susceptibilidades en el seno de la todavía pagana aristocracia romana: Krautheimer 1980, 2 y ss. No obstante se le puede considerar el iniciador de la política de secularización de los templos paganos, como ha señalado Caseau 2001, 89.

${ }^{36}$ Codex Thedosianus XVI, 10. 3. Templos rurales que seguirían abiertos siempre y cuando tuvieran como único fin servir a los juegos: Salzman 1987, 180-181.

37 Codex Theodosianus XVI, 10, 2-3 (346-354). Fernández 1981, 141. Arce 1975. Sanz Serrano 1995, 244. Se trata - a la espera de que se demuestra definitivamente la existencia de un edicto constantiniano al respecto - de "la primera constitutio mediante la cual el Imperio toma una postura represiva en este aspecto de la religión pagana": Buenacasa 1997-1998, 33, nota $\mathrm{n}^{\circ}$ 30. Para un seguimiento de la aplicación de esta normativa por Constancio II en África en la segunda mitad del siglo IV (366-367) conservamos el testimonio del obispo numidio Optato de Mileu.

38 "Si quis in agris templa sunt, sine turba ac tumulto diruantur": Codex Theodosianus XVI, 10, 16: Caseau 2004, 112. abandono de los espacios cultuales paganos ${ }^{39}$. El resto de destrucciones narradas por Eusebio de Cesarea respondieron no a una decisión oficial de Constantino sino a la espontánea intervención de miembros de la comunidad cristiana, alentada en ocasiones por personajes de una cierta relevancia, en muchos casos obispos. $\mathrm{O}$ al menos esta es la visión "bíblica" - violenta, fanática e intolerante - de la victoria del Cristianismo sobre el Paganismo ofrecida por escritores cristianos como Eusebio, todo un leit motiv de los textos hagiográficos e historias eclesiásticas de aquellos siglos ${ }^{40}$. Violencia, si, pero no generalizada sino minoritaria, puntual y limitada.

Será con el emperador Juliano cuando la política imperial sufra una cierta relajación respecto a las fuertes medidas represivas adoptadas por sus predecesores contra el paganismo; y muestra de esta actitud fue el llamado "Edicto de Tolerancia", por el que el emperador revocó las confiscaciones y "probablemente, restituyó los bienes que habían sido usurpados a los templos paganos, al tiempo que decretaba su reapertura" ${ }^{41}$. Al tiempo se endurecieron los castigos contra los destructores de templos y contra sus instigadores, entre los que se encontraban, como ya hemos indicado, muchos obispos (Buenacasa 1997-1998, 36-37). Pero tras su muerte en el 363, su política será abandonada y sus sucesores volverán a mostrar su predilección por la religión cristiana, aunque se tolere en algunos momentos la plena libertad de culto ${ }^{42}$; lo que no se permitió fue la práctica de determinadas costumbres paganas (la astrología, la aruspicina o estudio de las entrañas, los sacrificios nocturnos, etc. $)^{43}$. En el año 370, el imperio se erigirá nuevamente en protector de los cristianos al invalidar las medidas adoptadas por Juliano en contra de esta comunidad, de manera que sus sucesores recuperarán por decreto para la res privata el patrimonio que dicho emperador había restituido y cedido a los templos paganos ${ }^{44}$. Con los

${ }^{39}$ Fernández 1981, 141, Saradi-Mendelovici 1990, 47 y Arce 1982, 73-74 y 79. De esta actividad episcopal dan buena prueba los textos: Eleusio de Cízico (Hellespontus), Jorge de Alejandría (Aegyptus), etc., recogidos por Buenacasa 1997-1998, 33 y notas $\mathrm{n}^{\mathrm{os}} 33$ y ss., entre otros, y la actividad desarrollada por el obispo Teófilo de Alejandría, que ese mismo año destruyó el Serapeion y algo más tarde el templo de Dionisos contando con el consentimiento imperial: Fernández 1981, 143-144. Thélamon 1990. Fliche-Martín 1948.

40 Varios ejemplos los encontramos en Caseau 2001, 66 y ss.

${ }^{41}$ Buenacasaa 1997-1998, 36, nota $n^{\circ} 49$. Otro "edicto de Tolerancia" fue el otorgado a finales de abril del año 311 por el emperador Galeno y que puso fin a la persecución en el Danubio y Grecia: Vita Constantini, 11.

${ }^{42}$ Este es el caso de Valentiniano I: Ibidem, 38.

${ }^{43}$ Codex Theodosianus IX, 16 (364-371). Sanz Serrano 1995, 240.

${ }^{44}$ Ibidem V, 13, 3 y X, 1, 8. Buenacasa 1997-1998, 39. 
emperadores Graciano (el último en considerarse pontifex maximus), Valentiniano II y Teodosio I los templos más importantes de cada ciudad - según el testimonio de Libanio - permanecían cerrados, entrando a formar parte de la res privata de forma definitiva.

Será en tiempos de Teodosio I (a partir del 391) cuando, como ya se ha dicho, tenga lugar la destrucción de templos paganos, especialmente en las zonas rurales, si bien es verdad que a esas alturas de siglo los templos rurales situados no demasiado lejos de la ciudad ya eran saqueados para construir monumentos seculares en vez de iglesias ${ }^{45}$. Salvo iniciativas privadas que no contaban con el apoyo imperial, el reinado de Teodosio I destacará por su explícita política antipagana ${ }^{46}$; pero se trata de una actitud imperial, no eclesiástica ya que la Iglesia nunca tuvo intención de destruir los templos paganos de manera sistemática. Y es que no siempre la destrucción de los templos fue una consecuencia directa de su abandono. En muchas ocasiones y especialmente a partir del siglo $\mathrm{V}$ lo fue debido a los saqueos protagonizados por "monjes", los auténticos cristianizadores (bajo la dirección de los obispos) del mundo rural ${ }^{47}$; los monjes, aleccionados por los episcopi, fueron los primeros destructores de templos, pero no los más eficientes, ya que destruir un templo no era una tarea fácil: requería mano de obra y "maquinaria" especializada; los santuarios y altares que una vez habían sacralizado el paisaje eran ahora despreciados por "contaminar la tierra", de ahí que los primeros en sufrir esta "limpieza selectiva" o "destrucción selectiva" fueran los pequeños fana y los ídolos y estatuas que allí se encontraban ${ }^{48}$.

\subsection{EN HISPANIA}

Muy pocas son las noticias ofrecidas por documentación textual y arqueológica respecto a la destrucción

\footnotetext{
45 Caseau 2004, 129.

${ }^{46}$ Iniciativas como las que dieron lugar a la "reacción pagana" vivida en Roma en el bienio 393-394: Bloch 1945.

${ }^{47}$ Loring García 1986-1987. Buenacasa 1997. Como las protagonizadas por el obispo Porfiro de Gaza o las auspiciadas por San Juan Crisóstomo, obispo de Constantinopla (398-407), y financiadas por la noble constatinopolitana Teodora: Fernández 1981, 143 y 145. Caseau 2004, 130 y ss. Alentados por la actitud destructiva que los profetas Elías y Eliseo mostraron ante los ídolos, puede afirmarse que la destrucción de templos "fue obra fundamentalmente de los obispos y de los monjes" y que para ello contaron con el consentimiento imperial: Fernández 1981, 155.

${ }^{48}$ Para Occidente contamos con varios testimonios, como el del obispo Cesáreo de Arlés (469-542), que invitó a toda su feligresía a destruir los templos rurales y a erradicar el paganismo, y los de San Martín de Tours: Sanz Serrano 1995, 244. Caseau 2001, 100-103 y 2004, 130 y 132.
}

de templos paganos en Hispania (Sanz Serrano 1998). No obstante, se conoce una ley del emperador occidental Honorio (29 de enero de 399) dirigida a Macrobius ("vicarius diocesis Hispaniarum", con sede en Emerita Augusta) que prescribía la salvaguarda y conservación de la ornamentación de los edificios públicos e indicaba que cualquier petición para destruir un templo pagano o "desacralizarlo" debía ser estudiada personalmente por el emperador ${ }^{49}$ que, no olvidemos, ostentaba la posesión de algunos de ellos y, evidentemente, disfrutaba de las rentas que generaba tal patrimonio ${ }^{50}$. Con esta ley - que quizás sólo se aplicó en casos especialmente conflictivos y desde luego no afectó a los templos privados, que eran la inmensa mayoría - se intentaría también impedir las destrucciones espontáneas, abundantes en otras provincias imperiales en épocas anteriores ${ }^{51}$. La salvaguarda en Occidente frente a la erradicación de los restos paganos visibles en Oriente, especialmente en el mundo urbano, parece ser el motivo de esta actitud: los templos rurales serán los primeros en ser destruidos a manos de los cristianos ${ }^{52}$.

En la Península Ibérica, los obispos, como herederos de la antigua aristocracia fundiaria hispano-romana, también asumieron las funciones desarrolladas por las antiguas magistraturas municipales, entre otras las evergéticas, las relacionadas con la beneficencia. Y ahí tenemos como muestra la actividad constructora emprendida a mediados del siglo VI por el obispo Justiniano de Valencia, miembro de una de las "familias sacerdotales" más importantes de Hispania ${ }^{53}$. Pero también asumieron otras mucho menos "honoríficas", como la dirección de muchos ataques contra los templos paganos, que dicho sea de paso, no siempre estuvieron bien vistos por las autoridades religiosas y civiles, pues es sabido por todos que, si por algo se caracterizaron los primeros "monjes" hispanos, fue por sus enfrentamientos con las altas jerarquías eclesiásticas,

49 Codex Theodosianus XIV, 10, 15. Fernández 1981, 142. Sanz Serrano 1995, 244. Sobre la desacralización de los templos paganos: Caseau 2001, 86 y ss.

${ }^{50}$ Posesión compartida con las personas que reclamaban su propiedad (generalmente aquellos que los habían construido y mantenido) y con los municipios, con las curias municipales: Buenacasa 1997-1998, 44 y ss.

${ }^{51}$ Según un texto de la iglesia copta que ha llegado hasta nosotros en una versión tardía (siglo XIII), la Synaxaire, el patriarca egipcio Teófilo (385-412) habría destruido multitud de templos para construir dos iglesias y dos "asilos para extranjeros": Caseau 2001, 69.

${ }^{52}$ Caseau 2004, 106.

${ }^{53}$ Pues tres de sus hermanos fueron también obispos: Justo de Urbel; Elpidio de Huesca y Nebridio de Egara: Escribano 1977, 75; García Moreno 1988, 148-150 y 1990; Orlandis 1991, 31-32. 
especialmente con los obispos, a los que no siempre obedecían ${ }^{54}$.

Para Hispania no podemos afirmar que las fuentes tardo-antiguas sean precisamente prolijas respecto a las noticias referentes a la destrucción de los templos, ya sean urbanos o rurales ${ }^{55}$. Las escasísimas y localistas referencias que poseemos sobre destrucciones de templos paganos tan solo reflejan que estas ya pudieron haber tenido lugar antes del 399 (más difícil sería aceptar la posibilidad de que en Hispania no tuvieron lugar, y también mucho más difícil de explicar) ${ }^{56}$, tal y como ocurre en la Gallia ${ }^{57}$ o en Britannia (Lewis 1966), y que también pudieron afectar a los santuarios mitraicos, aunque no tenemos testimonios que lo certifiquen ${ }^{58}$. Pero estas destrucciones, insistimos, nunca debieron ser numerosas, ni siquiera generalizadas (Vriezen 1995),

\footnotetext{
${ }^{54} \mathrm{La}$ anachoresis o ascetismo, el aislamiento social del monje o solitario, la huida, fue en cierta medida causa importante de la marginalidad propia del monaquismo primitivo "subproducto de la desintegración del tejido social de la ciudad en la Antigüedad tardía..." que todavía estará presente en Hispania varios siglos después: Teja 1993, 24. Orlandis 1984. Muy acertadamente se ha justificado la animadversión eclesiástica y civil hacia el movimiento monástico desde finales del siglo IV y principios del V en la Gallaecia (cuando el Cristianismo era ya un fenómeno religioso consolidado en todo el Imperio) por su carácter aislacionista, bucólico y antisocial vinculado a una cultura clásica pagana que se adapta a la nueva aristocracia urbana (Teja 1993, 12 y ss.: "se entiende la dificultad para comprender un fenómeno como el monacato y una figura como el monje, que... optaba por el desierto... para los antiguos la no ciudad, la ausencia de sociedad y de vida civilizada... todo aquello que no estaba sometido a la escala de valores por la que se regía la ciudad era la barbarie, la incivilización... fuera de allí imperaba el peligro físico, la ausencia de ley...”. Plácido 1990, 200; y tanto fue así que en los primeros momentos se llegó a identificar al monje con un bandido y en ocasiones con un mártir: Giardina 1983. Vid. también López Quiroga, 2004.

55 Tal y como se afirma para otras partes del Imperio: Caseau 2001, 62 .

${ }^{56}$ Codex Theodosianus XVI, 10, 15. Puesto que esta ley imperial del 399 prohibía la destrucción de los edificios públicos (entre los que se encontraban los templos) es de suponer que estas tendrían lugar desde varios años antes también en Hispania: Sanz Serrano 1995, 239. Buenacasa 1997-1998, 47, nota $n^{\circ} 114$. Una primera valoración en conjunto de la destrucción de los templos durante el periodo que nos ocupa la efectuó Fernández 1981.

${ }^{57}$ Especialmente por a la acción de San Martín de Tours, destructor y cristianizador de templos y santuarios paganos (Bibracta, Sequana, de Mercurio): Mâle 1950, 35-46.

${ }^{58}$ Muchos de los Mithraea de la Galia, Germania y Britannia (que no fueron considerados espacios sagrados por la legislación romana) fueron abandonados ya a finales del siglo III; algunos fueron desmantelados y sus materiales reutilizados en la reparación de fortificaciones: Caseau 2001, 78, nota ${ }^{\circ} 91$ y 2004, 117.
}

aunque al igual que en el resto de las provincias del Imperio, las que tuvieron lugar debieron ser más tardías: como ya señaló Mango (1994), la antigua cultura pagana estuvo viva mientras lo estuvo la ciudad y las elites urbanas, lo que en su opinión sucede hasta el siglo VII. Además hay que tener en cuenta que el reino suevo fue, hasta mediados del siglo $\mathrm{V}$, un reino pagano. $\mathrm{Y}$ también hay que suponer que fueron protagonizadas por monjes, obispos y soldados, como ocurrió en Siria y en la Galia, y que contaron con la aquiescencia imperial o cuando menos de las autoridades locales ${ }^{59}$.

Ya en el siglo VI contamos con testimonios escritos que hablan de la destrucción de iglesias y conjuntos monásticos y/o cenobíticos (entre otros el de "Punta de l'Illa de Cullera, en Valencia) en el marco del enfrentamiento entre Leovigildo y su hijo Hermenegildo ${ }^{60}$ : ¿guardaban estos conjuntos relación con antiguos santuarios paganos? Esta es una cuestión que, al día de hoy, carece de respuesta. Y otro tanto ocurre con uno de los pocos, por no decir el único, testimonio de destrucción de templos conservados en Hispania; procede de la Betica y no tiene confirmación textual sino arqueológica: se trata del templo de la C/ Claudio Marcelo de Córdoba, arrasado, destruido intencionadamente, a finales del siglo III o principios del IV, "por parte del poder cristiano y no como decadencia de lo público", y posteriormente ocupado por construcciones domésticas (Marfil 2000, 119; Carrillo et alii, 1999). A la hora de explicar este hecho no podemos olvidar que Corduba fue la patria del obispo Osio, consejero y mentor del emperador Constantino "el Grande", una de las personalidades hispanas más emblemática de la primitiva iglesia hispana; y que su participación en el proceso de desarrollo y difusión de la nueva religión fue esencial (Sánchez 2002, 325).

\section{LA CONSERVACIÓN Y RESTAURACIÓN DE LOS TEMPLOS PAGANOS}

\subsection{EN EL IMPERIUM}

Desde el reinado de Constantino "el Grande" se aprecia un descenso considerable del número de inscripciones que hacen referencia a las construcciones y

\footnotetext{
${ }^{59}$ Fernández 1981, 155. Al menos así ocurrió también en Asia Menor y Egipto entre los siglos IV-VI: Beatrice 1996, 25. Las acciones destructivas emprendidas por San Martín en la Galia circa 375 no habrían sido posibles sin las amigables relaciones del santo (anteriormente soldado) con los miembros de la administración y de la aristocracia galo-romana: Stancliffe 1983, 335.

${ }^{60}$ Nos referimos en concreto a un texto de Gregorio de Tours al que hace alusión Roselló 1995, 45.
} 
restauraciones de templos en las áreas sagradas urbanas, una tendencia generalizada que tan solo se romperá durante los reinados de Juliano y Valentiniano en África, momentos en los que "el culto pagano, simplemente, se había recluido en el interior de los domicilios privados" (Lepelly 1979, 345-347. Buenacasa 19971998, 34). Durante el mandato de su nieto, el emperador Juliano, y durante la primera mitad del siglo $\mathrm{V}$, la política imperial dará un giro y se orientará a la restauración de los templos, llegándose incluso a emprender la construcción de otros nuevos, al menos en Constantinopla (Arce 1975, 207-208), y a darse el caso - amparándose en una constitutio del año 363 - de que aquellos particulares que habían procedido a saquear un templo, a convertirlo en vivienda o a desmantelarlo para aprovechar sus materiales en la construcción de edificios cristianos fueron obligados a reconstruirlos o bien a pagar su coste ${ }^{61}$. Incluso se llegó a institucionalizar una ayuda económica a las curias urbanas para que reconstruyeran, entre otras edificaciones públicas, los templos ${ }^{62}$. Una actividad que llegó a poner en práctica algún que otro obispo, como Pegaso de Illium (la antigua Troya), que dirigió sus esfuerzos a la salvaguarda de estas edificaciones paganas (Saradi-Mendelorici 1990, 52).

Hacía ya unos cuantos años (desde el 342 ó 346 aproximadamente) que el Imperio se había dejado de preocupar por la conservación de los templos suburbanos, de los santuarios situados extramuros, en el ager (Caseau 2001, 89-90). Y la situación no era mejor en las ciudades. Los templos urbanos comenzaron a ser cerrados, y por tanto a perder sus funciones públicas, a partir de mediados del siglo $\mathrm{IV}^{63}$; no obstante los emperadores intentaron preservarlos como puntos de referencia urbanística pero el Imperio no estaba ya en condiciones de cargar, económicamente hablando, con la conservación de todos los templos que se encontraban bajo su jurisdicción, de ahí el proceso de secularización y privatización al que se vieron abocados muchos de ellos a lo largo de los siglos IV-V. Y una de las fórmulas de secularización o privatización adoptadas por los emperadores a partir

\footnotetext{
${ }^{61}$ Codex Theodosianus IX, 17, 5. Dupont 1979. Esto es lo que le ocurrió a Thalassius, un prefecto convertido al cristianismo que transformó en vivienda un templo pagano de su propiedad que poseía en la provincia de Phoenicia: su casa fue confiscada y fue obligado a reconstruir el templo (testimonio recogido por Arce 2005, 245). Y al obispo Marcos de Arethousa que a mediados del siglo IV tuvo que aceptar, tras amenazas y torturas, la reconstrucción del templo que había destruido parcialmente para construir una iglesia (testimonio recogido por Caseau 2001, 90).

${ }^{62}$ Así ha interpretado Buenacasa 1997-1998, 38 la ley de Juliano por la que se restituían las rentas usurpadas a los templos.

${ }^{63}$ Codex Theodosianus, XVI 10, 4; 10, 7 y 10, 10 (346-391).
}

de 398 , pero especialmente desde 401, fue la de instalar en ellos corporaciones profesionales o bien cedérselos o venderlos a particulares, incluidos los obispos ${ }^{64}$.

\subsection{EN HISPANIA}

Para la reconstrucción y conservación de templos paganos en la Hispania de la Antigüedad Tardía apenas contamos con noticias ${ }^{65}$. El silentium de las fuentes documentales respecto a las medidas adoptadas por el emperador Juliano da a entender, en opinión de Javier Arce (1975, 201 y 214), que no tuvieron repercusión en estas latitudes de Occidente y que los templos permanecieron cerrados ${ }^{66}$. Fuera así o no, el hecho es que hay que suponer que desde los años 398-399 los restos abandonados de los fana localizados en el ámbito rural hispano fueron susceptibles de ser utilizados libremente para otras construcciones y que a partir de 425 la legislación imperial dejará de preocuparse seriamente por la conservación de los edificios públicos, función que será asumida desde entonces por los obispos (Arce 2005, 228 y 247).

Es una realidad que la suerte que corrieron los santuarios paganos no fue, ni mucho menos, uniforme, de manera que en el caso del ninfeo de la ciudad de Valentia este fue repavimentado "en un momento indeterminado" del siglo IV, tal vez durante el mandato del emperador Juliano lo que testimonia la pervivencia entonces del culto al dios de la aguas (Ribera 2000, 23). En las ciudades de Hispania, como en otras provincias del Imperio, se constata la larga pervivencia de la edilicia pública romana durante la Antigüedad tardía, al menos hasta el siglo V, momento en el que el Foro y otros edificios públicos (circos, anfiteatros, hipódromos, etc.) perderán su función original (Grosse 1947, 65; Fuentes 1999, 41; Ribera-Roselló 1999). La perdurabilidad en el tiempo de los templos paganos en Hispania estaría en relación no sólo con el hecho de que estuvieran protegidos por su utilidad pública y belleza ${ }^{67}$; también - o al menos eso se deduce del caso concreto de Valentia - "en la temprana adaptación para el culto cristiano de alguna de las antiguas sedes del poder civil o del culto pagano, como la curia, que se mantiene en pie hasta el siglo X, o el antiguo edificio administrativo, donde se encontraría el lugar del martirio de San Vicente, que se derrum-

\footnotetext{
${ }^{64}$ Ibidem, XV, 1, 40-41.

${ }^{65}$ Y así lo recuerdan Arce 1975, Murga 1979 y Buenacasa 1997-1998.

${ }^{66}$ Una hipótesis que fue cuestionada por Buenacasa $1997-$ 1998, 37, nota $\mathrm{n}^{\circ}$ 58: "El argumento ex silentio no siempre es concluyente y quizás cabría valorar el desconocimiento, o desinterés, que muestran los escritores orientales con respecto a los acontecimientos de la pars Occidentis".

${ }^{67}$ Codex Theodosianus XVI, 10, 8 (382) y XVI, 10, 15.
} 
bó en el siglo V" (Ribera-Roselló 2000, 168). Un claro ejemplo de conservación, incluso de rehabilitación, de espacios públicos (como el foro, sede del culto imperial, las thermae, etc.) lo encontramos en Complutum (Alcalá de Henares) y Tarraco a partir de finales del siglo III, principios del IV (Rascón-Sánchez 2000, 235; Macias 2000,260 y 271 , nota $\left.n^{\circ} 68\right)$.

\section{LOS SPOLIA: MATERIAL PAGANO PARA LA CONSTRUCCIÓN DE EDIFICIOS CRISTIANOS}

\subsection{EN EL IMPERIUM}

Fue la creciente y progresiva desprotección legal a la que se vio abocada el paganismo a partir del 313 y su posterior y lógica "desacralización" lo que propició un cierto "gusto" por la reutilización de los materiales (constructivos y decorativos) y equipamiento cultual de los templos paganos en la edificación de los edificios cristianos en la Antigüedad tardía; y parece más que probable que esta práctica se desarrollase con cierta asiduidad a partir del 15 de noviembre de 407, fecha en la que en una constitución imperial dirigida al pretorio Curcio se declara "de utilidad pública" todos los templos públicos; se retiran los subsidios annonios a los templos; se ordena retirar las estatuas, destruir las arae y los templos privados y se autoriza a que puedan ser utilizados como "cantera" para reparar edificios públicos y, desde luego, a partir de $425^{68}$. La reutilización de materiales constructivos y decorativos procedentes de los edificios públicos para la construcción de iglesias es un hecho a partir del siglo IV y, sobre todo, en el VI ${ }^{69}$. Pero dicho material en Occidente fue empleado preferentemente en la construcción de edificios seculares (Caseau 2001, 102; Pensabene 2004).

Pero también hubo spolia fuera de la ley. Una práctica, el saqueo de templos con vistas a reutilizar sus materiales, que fue duramente sancionada a lo largo del siglo IV por diversas "constituciones" ${ }^{70}$. Sin embargo la valoración económica del material constructivo procedente de los edificios públicos hizo que fueran los propios

${ }^{68}$ Ibidem, XVI, 1, 19, 1-2. Fernández 1981, 142. Aunque no únicamente, ya que este material también fue empleado en la edificación de viviendas particulares, como señalan Murga 1979 y Saradi-Mendelorici 1990, 50-51.

${ }^{69}$ Más de 300 casos ha contabilizado, solo para Palestina, Tsafrir 1998. En estos momentos fue cuando se desmontaron los muros de oppus vitatum del ninfeo de Valentia: Pascual et alii 1997.

${ }^{70}$ Tanto del Codex Iustinianus (VIII, 10, 6, 321; VIII, 10, 7, 363) como del Theodosianus (XV, 1, 19, 376; XV, 1, 37, 398): Buenacasa 1997-1998, 33, nota ${ }^{\circ} 34$. Caseau 2001, 70-71. emperadores y las elites eclesiásticas ${ }^{71}$ los que en ocasiones llegaron a auspiciar su expoliación, casi siempre obligados por la necesidad de encontrar recursos económicos suficientes para sufragar sus empresas militares, construir arcos conmemorativos ${ }^{72} \mathrm{o}$ reparar vías, puentes y acueductos, como se señala en sendas "constituciones" de los años 397 y 399 dictadas en pleno reinado de los emperadores Teodosio y Arcadio ${ }^{73}$. Incluso antes, en tiempos de Juliano, ya se constata el uso de los templos como fuente de material constructivo para la edificación de iglesias; por eso ordena la restauración de los templos (Caseau 2001, 69). En otras ocasiones la iniciativa restauradora partirá de particulares, en ocasiones de altos funcionarios cristianos ${ }^{74}$. De la asiduidad con la que ya en el siglo IV se producían estos spolia sobre los monumentos paganos, principalmente santuarios o templos y tumbas o mausoleos, da muestra la constitución de Graciano (376) dirigida al Senado de Roma con la que se pretende impedir la dilapidación, por los magistrados, del patrimonio inmobiliario antiguo en provecho de nuevas construcciones (Kunderewicz 1971).

Gracias al estudio publicado por José Luis Murga (1979) se conoce la existencia en la Antigüedad tardía de mercados en los que se ponían a la venta elementos y materiales procedentes de los edificios cultuales paganos ${ }^{75}$ (pedestales, estatuas, frontones, mármoles, etc.). De la procedencia de los mismos puede darnos una idea el texto de Eusebio de Cesarea que cuenta el proceso constructivo del oratorio del Santo Sepulcro en Jerusalén por Constantino en el segundo cuarto del siglo IV ${ }^{76}$.

${ }^{71}$ Como el obispo de Aigai, que hacia el 360 aprovechó un templo dedicado a Asclepio para construir la iglesia, creándose así "un précédent pour l'utilisation des temples comme carrières de pierre": Couseau 2001, 89.

${ }^{72}$ Como ocurre con el "Arco de Constantino": Ibidem, p 76.

${ }^{73}$ Codex Theodosianus XV, 1, 36 (397) y XVI, 10, 16 (399). Caseau 2001, 71 y 2004, 129.

${ }^{74}$ Como el del senador siciliano Julio Fírmico Materno, que entre los años 342-350 incitó a los emperadores a desmantelar de oro y plata los ídolos paganos para utilizarlos como amonedación: Barnes 1989, 331-332. O los casos relatados por Amiano Marcelino (relativos a las profanaciones realizadas por cortesanos del emperador Constantino II, 337-361) y Libanio (sobre las actuaciones de Orión y Teodulo): Buenacasa $1997-$ 1998, 35, nota $n^{\circ} 48$.

${ }^{75}$ En uno de estos mercados fueron vendidos probablemente los adornos que en un principio embellecieron el templo de Fortuna en Antioquia, despojado de los mismos en el año 359 para ser utilizado como escuela de retórica: testimonio recogido por Buenacasa 1997-1998, 49.

${ }^{76}$ Vita Constantini Libro III, 26-27 (291). Tras ordenar demoler el templo pagano construido sobre el sepulcro de Cristo, "no se detuvo sólo en esto la muestra de su celo, sino que una vez más ordena que los materiales de derribo, de piedra y madera, sean recogidos y arrojados lo más lejos posible de la comarca...". 


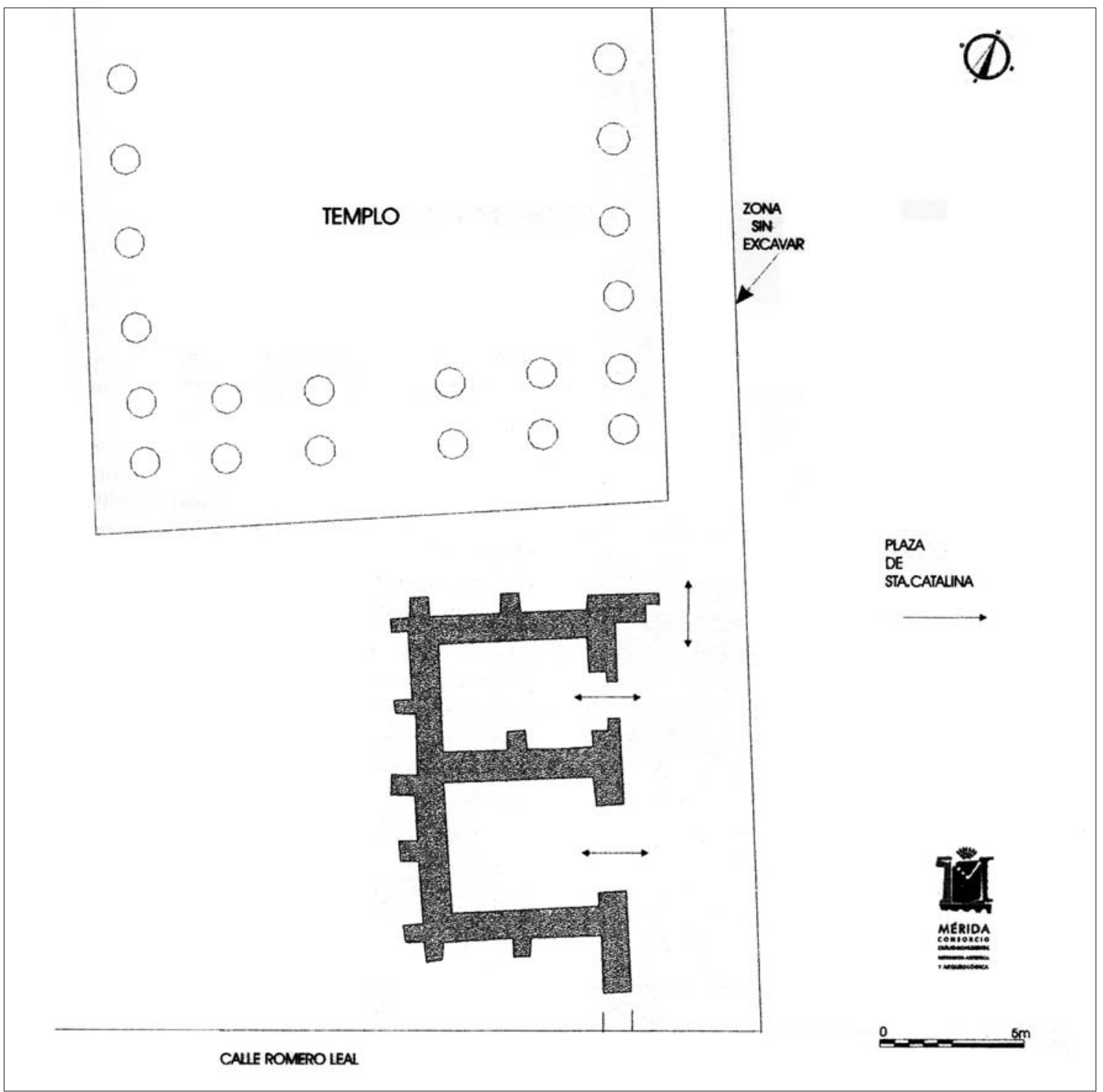

Figura 1. Templo de Diana (Emerita Augusta), de Mateos - Alba 2000.

\subsection{EN HISPANIA}

En la Hispania de la Antigüedad tardía la reutilización de materiales procedentes de spolia en edificios cristianos será un fenómeno que se acentúe en épocas más bien tardías, en la segunda mitad del siglo VII, pero que comenzará mucho antes ${ }^{77}$. Será a partir de los últi-

77 A este respecto son innumerables los ejemplos de spolia procedentes de edificios romanos (tanto públicos como privados) reutilizados en los edificios alto-medievales hispanos (CaballeroSánchez 1990), pero cuántos de estos restos proceden de templos es una cuestión que, hoy por hoy, desconocemos. mos años del siglo $\mathrm{V}$ cuando se proceda - y así ocurre en Valentia - al expolio sistemático de sus edificios públicos, que se convierten entonces en la principal cantera de la ciudad (Ribera 2000, 32); una característica común a los muros de esta época (Ribera-Roselló 2000, 163) refiriéndose a las construcciones efectuadas en la ciudad de Valentia en los siglos VI-VII - "es que la mayor parte de las piedras parecen proceder del expolio de paredes de época romana...". Y otro tanto ocurrió en Barcino - donde para la construcción del episcopium o palacio episcopal, a mediados del siglo $\mathrm{V}$, se reutilizaron pedestales, bases molduradas e inscripciones funerarias procedentes de edificios y espacios públicos 


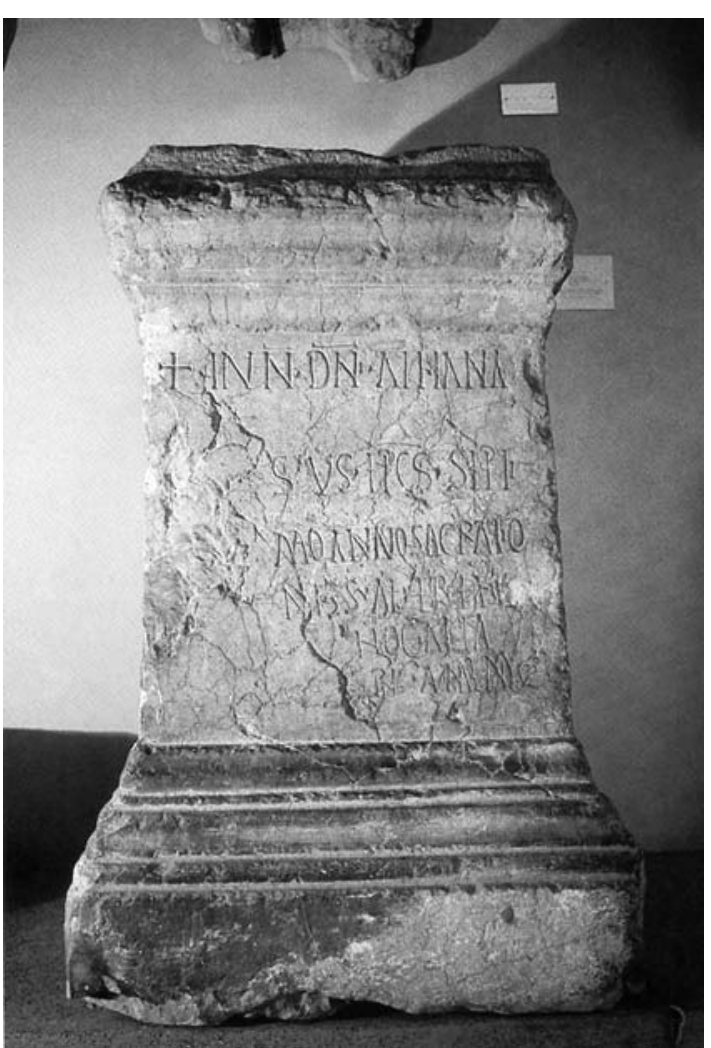

Figura 2. Ara del obispo Anastasio (Xátiva, Valencia), de Velasco 2000.

(Beltrán 2001,100) - y en Emerita Augusta, donde el recinto - que no el templo - dedicado a Diana (en el foro provincial), abandonado en el siglo IV, fue reocupado como vivienda palaciega ya en época emiral (Mateos Alba 2000, 148 y 160-163. Fig. 1).

En raras ocasiones, por no decir en ninguna, se podrá admitir que los materiales reutilizados como material constructivo o decorativo proceden de templos paganos; y así acontece en el complejo palacial o villa aúlica de "Pla del Nadal" en Riba-Roja de Túria (Valencia), construido reaprovechando restos materiales procedentes de los edificios públicos de la antigua Edeta; una reutilización llevada a cabo ya en la segunda mitad del siglos VII que "no debió resultar ideológicamente neutra, como restauración tácita del prestigio arquitectónico del extinto estado romano..." (Empar-Lerma 2000, 136). Pero esas raras ocasiones se produjeron. Este es el caso del pedestal que, reutilizado como pie o soporte de altar, contiene el texto de su consagración por el obispo Anastasio de Xátiva, lo que habría tenido lugar hacia el 660; un pedestal "que debió contar con una primera inscripción en una de sus caras y que posiblemente fue borrada para ser reutilizado, en su cara opuesta, con la siguiente inscrip-

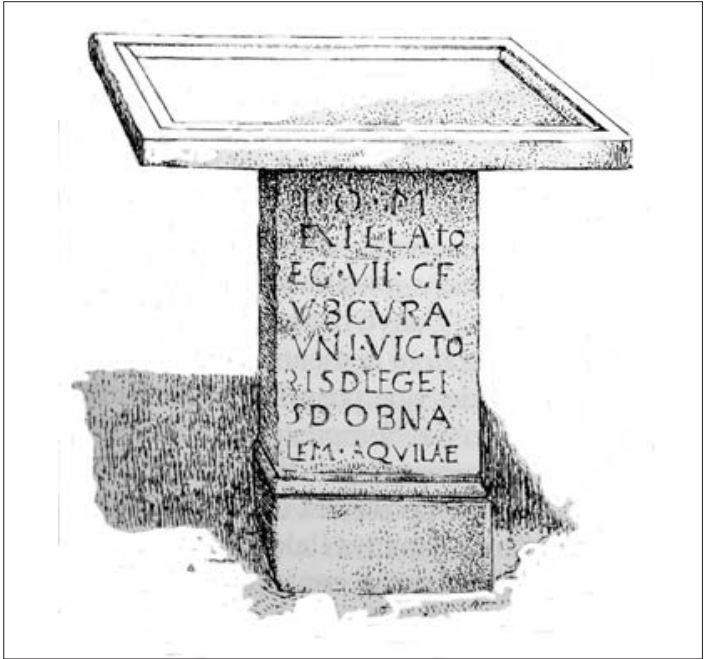

Figura 3. Reconstrucción del altar de la basílica (c. 660) de Ampurias, de Nolla - Sagrera - Palahí y Vivó 1995.

ción..." (Velasco 2000, 82). Pedestales, cipos y columnas fueron dos de los elementos más reutilizados en la erección de altares, especialmente como soportes de arae, de manera que al ya citado de Xátiva podríamos añadir los casos de Ampurias, en la Tarraconense ${ }^{78}$ y algunos en la Gallaecia (Figs. 2-3). Y también se emplearon como material constructivo las arae en edificaciones ya plenamente alto-medievales, como $\mathrm{St}^{\mathrm{a}}$. Lucia del Trampal, en Alcuéscar, Cáceres ( $2^{\mathrm{a}}$ mitad del siglo VIII- s. IX $)^{79}$.

Un claro caso de spolia podría encontrarse en Sâo Miguel da Mota (Terena, Portugal), una construcción que - según los resultados obtenidos tras últimos trabajos arqueológicos llevados a cabo en 2002 - no termina de corroborar la supuesta vinculación entre su dedicación pagana local a Endovellicus y la cristiana de San Miguel ${ }^{80}$, pues el edificio cristiano no se alzó sobre un

${ }^{78}$ Durante las excavaciones de 1846 se localizó una mensa altaris o ara (actualmente en el Museo Arqueológico de Cataluña, sección de Gerona) realizada con mármol de Paros; una pieza reaprovechada con unas dimensiones de 106 x 76 × $6 \mathrm{~cm}$. que descansaba sobre un pedestal monolítico con una dedicatoria a Júpiter, que haría las veces stipes. Tal y como ocurre en otros lugares se aprovecha un pedestal en desuso para hacer las veces de stipes de un ara: Nolla - Sagrera - Palahí - Vivó 1995, 98-102; Nolla 2000, 248.

${ }^{79}$ Catorce de dichas aras dedicadas están dedicadas a la diosa indígena Ateacina, lo que ha dado pie a pensar que allí (o en sus cercanías) se encontraba un santuario dedicado a esta diosa: Caballero 2003, 15-20.

${ }^{80}$ Como había señalado PEREIRA 1889. Una continuidad que no suele ser muy habitual en la península: CABALLERO SÁNCHEZ 1990, 442-445 y 464-465, pero sí, al parecer, en otras latitudes occidentales: MÂLE 1950. DÍEZ 1984. 

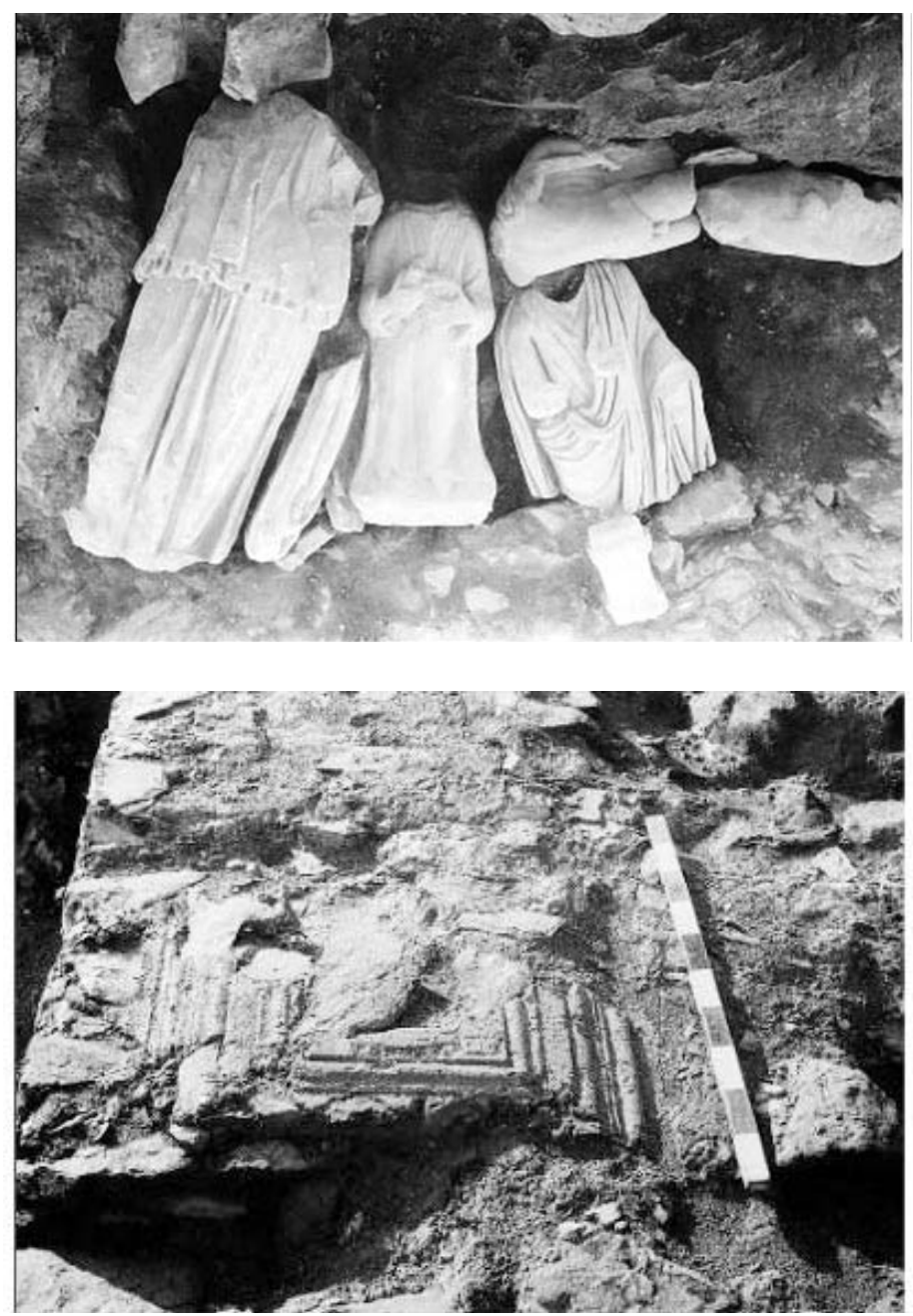

B

Figura 4. A-B. Restos escultóricos y de un posible altar localizados en las inmediaciones de Sâo Miguel da Mota.

(Terena, Portugal), de Guerra - Schattner - Fabiâo y Almeida 2003.

santuario prerromano dedicado a la deidad local. No parece existir por tanto una superposición topográfica e icnográfica entre un antiguo templo pagano y una ermita dedicada S. Miguel ${ }^{81}$. Sin embargo, recientes excavaciones han sacado a la luz seis esculturas que han sido datadas entre los siglos I y II, entre ellas una "portadora de ofrendas", que fueron cuidadosamente depositadas, sepultadas, en un pozo tras haber sido mutiladas, lo que da a entender la más que probable existencia de un edificio notable en la zona, tal vez un santuario (Fig. 4, AB). Pero tan solo eso; por el momento solo se puede afirmar que el templo cristiano fue construido ex novo, eso

\footnotetext{
${ }^{81}$ Como señalaron entre otros Almeida 1962, 119-121 y Fontaine 1982, 441
}

si, reutilizando materiales antiguos (Guerra - Schattner - Fabiâo - Almeida 2003, 461 y ss). De ahí que por el momento incluyamos este caso en el apartado de spolia y no en el de transformaciones.

En cualquier caso el uso o reaprovechamientos de spolia de templos paganos en edificios cristianos únicamente nos indicará, nos ofrecerá, una cronología en términos "post quem", es decir, señalará el momento en el que se pudo construir el edificio en el que se encuentran los restos, pero nunca el momento concreto en el que se efectuó el expolio. Esto es lo que ocurre, por citar algunos ejemplos, en el ábside de herradura de la basílica de la Almoina y en la capilla funeraria conocida como "Cárcel de San Vicente", ambos en la ciudad de Valencia o en el probable edificio cultual localizado en el interior del recinto fortificado de "Valéncia la Vella" en 
Riba-Roja de Turia, también en la comunidad valenciana (Roselló 2000, 129-130); aunque todos estos edificios están datados en los siglos VI y VII es de suponer que el espolio tuvo lugar en siglos anteriores (IV-V), pero por el momento resulta imposible precisar más ${ }^{82}$.

\section{LA TRANSFORMACIÓN DEL TEMPLO PAGANO EN TEMPLO CRISTIANO}

\subsection{EN EL IMPERIUM}

Muchos fueron los factores que concurrieron a la hora de promover la transformación de un templo pagano en iglesia cristiana; y uno de los más importantes fue el económico, la "ambición de riquezas", pues como recuerda Carles Buenacasa (1997-1998, 25), "la iglesia cristiana local recibiría los lotes de tierra que habían servido al mantenimiento del santuario al cual sustituye, con lo que, de esta manera, veía aumentar su patrimonio". Otro factor fue el ideológico, ya que para algunos tal transformación significaba el triunfo o victoria de la comunidad cristiana, de la ecclesia, sobre la pagana.

En diversas provincias del Imperio esta transformación fue liderada por los obispos aprovechando - tal y como se ha dicho - las medidas legales o "constituciones" promulgadas por Constante I y Constancio II ${ }^{83}$. Hay que destacar que no hay constancia - ni documental ni arqueológica - de una conversión sistemática de los templos paganos en santuarios cristianos en tiempos de Constantino I ya que la única política generalizada que desarrolló durante su reinado, la confiscación de los tesoros de los templos paganos ${ }^{84}$, no ha de verse como una

${ }^{82}$ De lo que si tenemos testimonio, aunque ya en el siglo VI, es de la erección de ecclesiae en edificios o espacios públicos; esto ocurre en el anfiteatro de Tarragona, en el que fueron martirizados el obispo Fructuoso y los diáconos Augurio y Eulogio en el 259; allí, en la arena, se construyó un edificio cultual en los siglos VI-VII a base de spolia, pues sus muros fueron alzados aprovechando los asientos de los graderíos: Palol 1953; Keay 1996, 38; Ted'a 1990, 219-223 y 234; Macias 1999, 229 y Macias - Menchon - Muñoz 2005, 44. Y también en la Neapolis de Ampurias (Girona), donde la primera construcción religiosa, una cella memoria, fue erigida reaprovechando el antiguo edificio termal tardo-republicano: Nolla - Sagrera Palahí - Vivó 1995; Nolla 2000, 248. Para las edificaciones cristianas sobre estructuras termales en Hispania: Fuentes 2000; Fernández - Zarzalejos 2001; Jiménez - Sales 2004.

${ }^{83}$ El obispo de Tarso (Cilicia), Marcos de Arethusa (Syria Salutaris), etc.: Buenacasa 1997-1998, 33, notas n ${ }^{\text {os }} 34-35$.

${ }^{84}$ Vita Constantini Liber III, 54, 4-7. Tesoros que, por otra parte, irán desapareciendo de los templos paganos a principios del siglo IV, momento a partir del cual el paganismo dejo de gozar del apoyo imperial (salvo el reinado de Juliano) y pasó a estar desprotegido. política dirigida a terminar con el paganismo (el mismo se intitula "pontifex maximus") sino como una disposición de carácter fiscal dirigida a la emisión o acuñación de monedas de oro, principalmente el solidus aureus ${ }^{85}$. Lo que si hubo por parte de Constantino "el Grande" fue un claro deseo, mediante la secularización de los templos, de impulsar la propagación del cristianismo, religión que desde entonces - especialmente desde el 313 contará con el favor imperial ${ }^{86}$. Con él el paganismo iniciará un camino que le conducirá a ser considerado una superstitio, y por tanto innecesaria para la felicitas del Imperio. Y otro tanto ocurrirá con sus más inmediatos sucesores. Aunque se desconoce el número total de templos que pudieron haber sufrido esta transformación a lo largo del siglo IV, lo que si sabemos es que para llevar a cabo la misma era necesario la previa "desacralización" otorgada por el emperador, ya que muchos de estos edificios eran, como ya se ha dicho, propiedad del Estado y su patrimonio estaba considerado por tanto res privata, bajo el control directo del emperador. Su pertenencia a la res privata será lo que permita a la Iglesia hacerse con la posesión de determinados terrenos, un proceso que sí se constata ya en tiempos de Constantino I (Chastagnol 1986. Buenacasa 1997-1998, 40. Caseau 2001, 70) ${ }^{87}$.

Parece ser, ya que los textos conocidos apuntan en esa dirección, que la cristianización de los templos paganos - al menos desde el punto de vista legislativo - se hizo más intensa a partir de la primera mitad del siglo V, de los reinados de los emperadores Honorio, Arcadio y Teodosio II (395-450), pero ésta jamás fue numerosa si tenemos en cuenta los casos conocidos. Y fue escasa por una sencilla razón: los cristianos consideraban los templos paganos espacios impuros y por tanto inapropiados para el "cultum $D e i "{ }^{88}$. Es lo que recientemente Ward-Perkins ha denominado "negative evidence" (2003, 286): la inmensa mayoría de los templos no fueron convertidos en iglesias ${ }^{89}$.

${ }^{85}$ Política, por otro lado, practicada ya por otros emperadores romanos, desde Caligula a Majencio, cuando escaseaban los metales preciosos: Piganiol 1932, 184.

${ }^{86}$ Una actitud que dejo huella especialmente en la numismática, pues a partir del 320-321 empiezan a escasear la representación de deidades en detrimento del labarus: Alföldy 1969, $39-43$ y $54-55$.

${ }^{87}$ Salvo, como ya hemos visto, durante el reinado de Juliano.

${ }^{88}$ De los trescientos templos cristianizados a lo largo del siglo VI señalados par el mundo proto-bizantino por Milojevic 1996, solo ochenta y tres de ellos se instalaron sobre la cella (recordemos ahora las palabras de Plinio que citábamos al principio de este trabajo); la inmensa mayoría aprovechará para ello el temenos; es más, parece evitarse el templo como lugar para construir una capilla: Callot 1997, 738-740. Para el caso de Italia, Vaes 1989 y Testa 1991; para África del Norte, Duval 1973 y para Grecia, Spieser 1976 y Foschia 2000-2002.

${ }^{89}$ En África del Norte algunas cellae fueron convertidas en baptisteria a partir del siglo V: Duval 1973. 
En ocasiones se trató de transformaciones realizadas a la fuerza ${ }^{90} \mathrm{y}$ en otras fue una consecuencia directa de disposiciones que mermaron alguna de sus funciones primordiales, como la adoptada por Honorio en el 399, que impedía la realización de sacrificios en el interior de los templos paganos ${ }^{91}$. La eclosión de la transformación tendrá lugar de manera muy significativa en el siglo VI; hasta entonces los casos será escasos y circunstanciales, vinculados a capítulos muy concretos de intolerancia y violencia religiosa "dans un sprit de conquête de l'espace" (Caseau 2001, 102). Será a partir de finales del siglo V, una vez que la memoria religiosa pagana del lugar casi ha desaparecido de la memoria colectiva, cuando los casos de transformación (parcial o total) se multipliquen (Deichmann 1939, 108-110).

Pero, ¿cuál fue la fórmula por la que la Iglesia se hizo con la propiedad de los templos paganos y con la de su patrimonio, paso previo a la "cristianización" de los mismos? Cabía una doble posibilidad respecto a los templos urbanos e imperiales: solicitarlo al emperador, en el caso de que estos se encontrasen bajo su directa dependencia o bien - y esta fue la más utilizada, pues el proceso era mucho más rápido - hacer la petición a la curia municipal, que era la encargada del mantenimiento de los templos públicos urbanos, de los templos situados intramuros (Buenacasa 1997-1998, 45). Un proceso que se agudizará de manera definitiva en la pars Orientalis del Imperio cuando en el 435 el emperador Teodosio II disponga que todos los santuarios debían ser destruidos o purificados para instalar en ellos la Santa Cruz, "el signo de la venerable religión cristiana" ${ }^{92}$. ¿Hubo alguna disposición similar para la Pars Occidentis? En opinión de Buenacasa (1997-1998, 45-46), esta no fue necesaria ya que existían los mecanismos necesarios desde hacía tiempo y venía siendo una práctica autorizada por el Imperio desde principios del siglo V.

Un ejemplo de la práctica de cristianizar los antiguos santuarios paganos para la construcción de oratorios lo encontramos en la actividad desplegada por San Martín

${ }^{90}$ Como ocurrió con la cristianización, entre los años 400404, del Marneion, el templo dedicado a Júpiter Marnaios, en Gaza: Fliche - Martín 1948, 21. Saradi-Mendelorici 1990, 53-54.

${ }^{91}$ Codex Theodosianus XVI, 10, 5. Este es el caso de la posible consagración, como edificio cristiano, del templo de la Dea Caelestis en Cartago entre los años 399-407: 1997-1998, 48 , nota ${ }^{\circ} 121$. Será precisamente en el capítulo del Codex que acabamos de citar ("De Paganis, sacrificiis et templis", que abarca desde el año 320 hasta el 435) donde se encuentre centralizada casi toda la legislación sobre este tema.

${ }^{92}$ Codex Theodosianus XVI, 10, 25 (435): "cunctaque forum fana templa delubra, si qua etiam nunc restant integra, praecepto magistratuum destrui concolationeque venerandae Christianae religiones signi expiari praecipimus": Sanz Serrano 1995, 244. Buenacasa 1997-1998, 45. Caseau 2001, 71. de Tours en la Galia del siglo IV, empeñado con su "obra" en afirmar la victoria de Cristo sobre los demonios ${ }^{93}$. Sea como fuere el hecho es que a mediados del siglo V el cronista Teodoreto de Ciro ya afirmaba que la mayor parte de los templos y altares paganos habían sido destruidos y sustituidos por edificios cristianos ${ }^{94}$. Y en la misma línea se encuentra San Juan Crisóstomo cuando afirma que en su época los altares, templos y fiestas en honor de los dioses eran cosas del pasado (Buenacasa 1997-1998, 48). Una ley imperial o edicto del 4 de noviembre de 451 castigaba, con penas de confiscación y muerte, la reapertura de los templos. El paganismo, como religión, llegaba a su fin; ya era una "religión ilícita", una superstición ${ }^{95}$.

¿Cómo fue el proceso de desacralización previo a la transformación de un espacio pagano en cristiano? Ya en la segunda mitad del siglo III, la "Vita" de Gregorio Taumaturgo $(† 270)$ nos presenta al santo presidiendo la exorcización-purificación de un templo pagano (acto que se llevaría a cabo grabando en sus muros el símbolo de la cruz) y la conversión al cristianismo del sacerdote que estaba a su servicio. El templo pagano era el hogar del demonio, y por tanto había que purificarlo (Caseau 2001, 68), de ahí que no resulte extraño encontrarnos muchos de sus elementos (columnas, estatuas, pedestales, etc.) "cristianizados" mediante signos grabados (cruces, crismones, etc.) ${ }^{96}$. Otra fórmula de cristianización, más indirecta, que ya encontramos en Siria a partir de finales del siglo IV, principios del V, fue la instalación de solitarios (monachus), de estilitas; implantación que dará lugar a la aparición de monasterios y cenobios en los espacios religiosos paganos ${ }^{97}$. Un proceso que desde el punto de vista constructivo contó con una dificultad de tipo estructural pues para la conversión de un templo pagano en templo cristiano en el primero había "que abrir un ábside en la cabecera". Esto fue lo que ocurrió con el templo de Cibeles en Autun, transformado por Martín de Tours en la iglesia dedicada a los Príncipes de los Apóstoles (Fernández 1981, 150-151).

La sustitución de los templos paganos por iglesias cristianas "es un proceso que se inicia con Constancio II, que se frena totalmente con Juliano y que, ante la aparente despreocupación de los emperadores de la

${ }^{93}$ Vie de Saint Martin 13, 9.

${ }^{94}$ Conocemos los casos de los templos de Zeus en Damasco, el de Baal en Heliópolis, el Partenón y el Erecterión en Atenas, el de Isis en File, el de Poseidón o Zeus en Constantinopla, el de la diosa Rhea en Cízico, etc.): Fliche - Martín 1948, 2021. Janin 1953, 345-347. Caillet 1996, 200.

${ }^{95}$ Codex Iustinianus, I, 11, 7. Fernández 1981, 142.

${ }^{96}$ Solo los altares y objetos de culto, así como las estatuas de las divinidades, serían destruidas: Caseau 2001, 105 y ss.

${ }^{97}$ Como ocurrió en Djebel Srir con el templo de Zeus: Callot 1997, 738-740. 

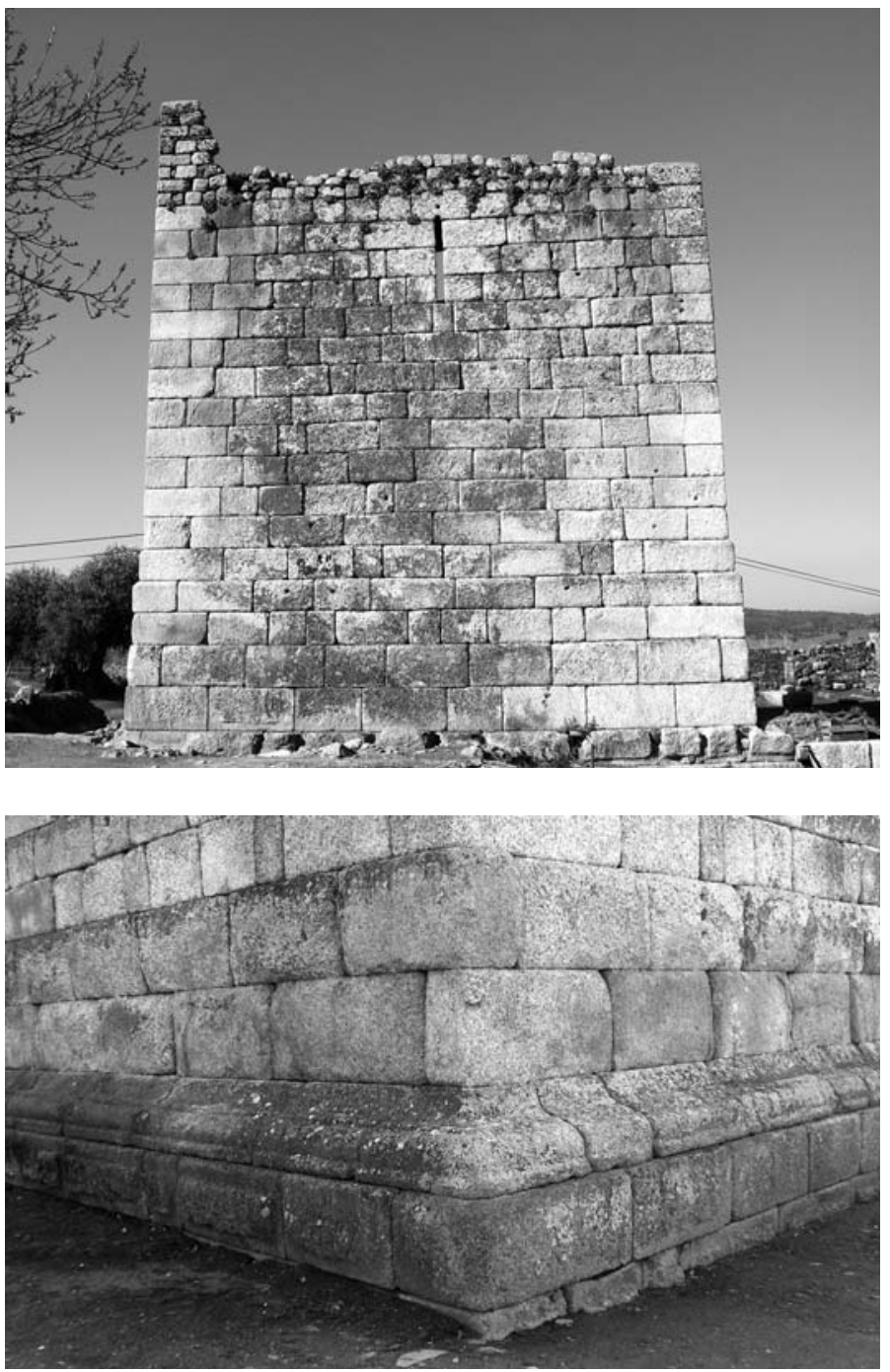

Figura 5. A-B. Fortificación templaria de Egiditania (Idanha-à-Velha, Beira, Portugal) construida en plena Edad Media sobre un templo romano y detalle del zócalo (Fotografías de los autores).

dinastía valentiniana, se renueva con extraordinario vigor con Teodosio I..." (Buenacasa 1997-1998, 46). Fue un proceso lento, con altibajos y auspiciado por el Estado, el que permitió a la Iglesia - desde tiempos de Constantino "el Grande" - hacerse con la propiedad de un santuario pagano para transformarlo en templo cristiano o bien edificar en su lugar una ecclesia que, obviamente, pasará a formar parte de su patrimonio. Pero esto fue lo excepcional en Occidente y en Hispania: en rara ocasión un templo pagano se convertirá en cristiano. Desde un punto de vista ideológico, religioso, no resultaba nada fácil para la Iglesia justificar la reutilización de un espacio impuro en el que se habían efectuado sacrificios paganos.
Pero también hubo otras causas que favorecieron la pervivencia de los templos paganos durante la Antigüedad tardía. En la parte occidental del Imperio se apoyó la conservación de los templos y santuarios paganos urbanos ante el miedo a colaborar en la desintegración de la topografía urbana clásica tradicional, ya que muchos de los principales espacios públicos de las ciudades todavía se encontraban organizados alrededor de las grandes áreas sagradas. La destrucción sistemática de estos templos habría acelerado la desestructuración de los centros monumentales tradicionales hasta entonces (basílicas, pórticos, arcos monumentales, termas, etc.) y de la red viaria urbana. Los cristianos al erigir sus edificios religiosos en lugares distintos a aquellos en los 
que se encontraban los templos o santuarios paganos tanto dentro como fuera de la ciudad - dieron lugar a una nueva topografía sagrada en la que muy a menudo, y de manera premeditada, se evitaba cualquier posible vinculación con los espacios cultuales paganos, con lo que además se contribuía a ralentizar el proceso de transformación urbanístico ${ }^{98}$.

Por lo general será más tarde, a lo largo de los siglos VI y VII cuando tengan lugar la mayoría de las transformaciones, una vez que los recuerdos de los sacrificios y de las ceremonias paganas habían casi desaparecido de la memoria colectiva, cuando los edificios ya se encontraban prácticamente en ruina; síntoma de dicho abandono será la autorización del emperador Heraclio al papa Honorio (625-638) para que este emplee las planchas de bronce del templo de Venus en Roma con el fin de reparar la basílica de San Pedro (Caseau 2001, 106). $\mathrm{Y}$ así ocurrió con los templos atenienses, convertidos en iglesias en el siglo VII, y con el primer caso de templo público romano convertido en iglesia: el "Panteón" de Agripa, convertido en Santa María de los Mártires por el papa Bonifacio IV (608-615) con la autorización del emperador Focas (Franzt 1965).

\subsection{EN HISPANIA}

¿Tuvo lugar dicha transformación en Hispania? ¿Qué factores la desencadenaron? ¿Cuál fue el comportamiento de las autoridades laicas y eclesiásticas al respecto? ¿Cuántos templos paganos se convirtieron en edificios cristianos? No conservamos ninguna evidencia arqueológica - afirma Javier Arce - que demuestre que en la Hispania del siglo $\mathrm{V}$ los templos paganos urbanos fueran trasformadas en iglesias; pero opinión muy distinta muestra García Moreno (1977-1978, 315), que cita los casos de Astigi (Écija), Iluro (Mataró) y Egiditania (Idanha-a-Velha, Beira, Portugal) ${ }^{99}$.

Lo que resulta una realidad incontestable, en nuestra opinión, es que salvo los conjuntos relacionados

98 "By aviding pagan sites, and by placing their churches elsewhere, generally scattered through the town or, indeed, outside it, the Christians created a wholly new sacred and monumental topography, that paid no heed to the traditional secular and pagan one of classical times. This must have hastened the disintigration of the traditional classical monumental centres, since secular basilicas, porticoes and monumental arches now stood next to abandoned and ruinous temples": Ward-Perkins 2003, 287.

${ }^{99}$ Respecto al caso de Egiditania debemos recordar que sobre el templo del forum se erigió, pero ya en momentos muy tardíos (ss. XII-XIII), una construcción defensiva cuya erección corrió a cargo de la orden del Temple (Fig. 5, A-B). No conocemos ningún testimonio que avale la posibilidad de su transformación en edificio cristiano durante la Antigüedad tardía. con el poder eclesiástico, con la "ecclesia principalis", las construcciones cristianas tardo-antiguas se focalizarán principalmente en localizaciones periféricas, extramuros, en el suburbium, y también que estas responderán principalmente a un culto de origen martirial. Si la transformación de los templos paganos urbanos en templos cristianos hubiera sido un proceso generalizado, ¿por qué no ha dejado huellas materiales? ¿Qué sentido tiene construir en los arrabales si cabía la posibilidad de hacerlo intramuros, en plena ciudad? Si los territoria hispanos del siglo $\mathrm{V}$ son tan inseguros como al parecer hacen ver las fuentes, ¿no se habría intensificado el proceso de cristianización de los templos urbanos?

Si la escasez de testimonios prevalece a la hora de conocer a fondo este proceso a lo largo y ancho del Imperio, no iba a ser menos el caso de una de sus provincias occidentales ${ }^{100}$. Carecemos de la suficiente información como para poder generalizar sobre cómo se llevó a cabo dicha transformación o cuál fue el número de edificios afectados por tan trascendente cambio, sobre todo para la institución eclesial, la gran beneficiada. Lo único que puede afirmarse al día de hoy es que no se trató de un proceso, ni mucho menos, generalizado y que su aplicación dependería del celo del magistrado de turno; más bien todo lo contrario: se trató de un proceso excepcional y cuando este tuvo lugar aconteció en momentos más tardíos, en el siglo VI, incluso en el VII. Parece ser que para la Hispania de los siglos IV y $\mathrm{V}$ se puede afirmar, a este respecto, lo mismo que para el resto del Imperio ${ }^{101}$.

Otra cuestión es la de la "sacralización" o "cristianización" de otro tipo de construcciones o espacios paganos, especialmente en el mundo rural: nos referimos a las cuevas, a los espacios rupestres o semi-rupestres, un tipo de hábitat muy relacionado con actividades paganas o

\footnotetext{
${ }^{100}$ Tan solo que ya a mediados del IV era un proceso consolidado y que hasta el siglo $\mathrm{V}$ inclusive "Tampoco se construyeron en ellos (se refiere a los templos paganos) muchas iglesias; este proceso empezó tarde, cuando ya no estaba presente en la sociedad el sentimiento antipagano", como recuerda Arce 2005,245 y 247. Apenas hay evidencias de esta transformación en la parte occidental del Imperio y cuando se encuentran datan de mediados del siglo VI en adelante (como es el caso de Honorato, obispo de Novara, que transforma un templo en iglesia en el 550 y de la conversión en iglesia del Templo de Concordia en Agrigento, en el 597): Ward-Perkins 2003, 287.

101 "The phenomenon of adaptation took very different forms in different parts of the Empire [...] The builders of Christian churches in the fourth- and fifth-century West avoided pagan sites, placing their basilicas in new locations - either on sites with no previous religious significance (as was generally true of churches within towns), or in sites already consecrated to Christian use by the bones of the martyrs (in the case of extramural churches)...": ibidem, 286.
} 


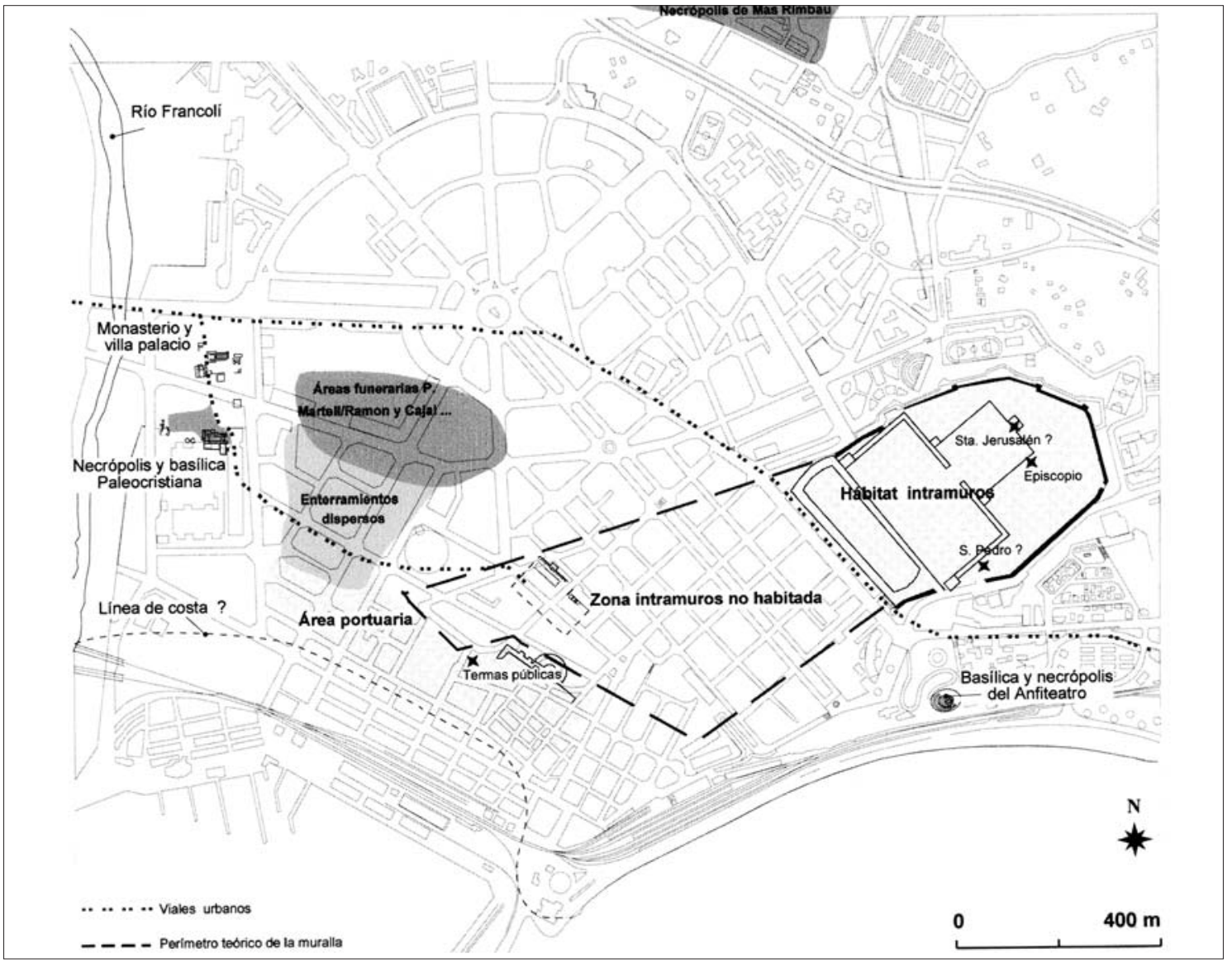

Figura 6. El Concilum Provinciae Hispaniae Citerioris de Tarraco, de Macías, Menchón y Muñoz 2005.

heréticas ${ }^{102}$. Un hábitat de este tipo, con fuertes reminiscencias paganas, como es el berciano, fue el elegido por el joven y noble godo Fructuoso a mediados del siglo VII para dar rienda suelta a su espiritualidad y, de paso, proceder a la reorganización religiosa del territorio ${ }^{103}$.

${ }^{102}$ Toda vida individual, por aislacionista, era tenida por potencialmente herética (recordemos el Priscilianismo) ante los ojos de gran parte de la alta jerarquía eclesiástica hispana. En la homilía que San Leandro dirigió a los asistentes al III concilio de Toledo se ha observado una extraña visión metafórica que relaciona herejías y cavernas: "escondidas (las herejías) en sus cavernas, en las que recogen unas riquezas parciales...": CVH 1963, 140.

${ }^{103}$ Luengo 1961, 28. Para Estepa 1986, 11-12, el santuario de Covadonga, en tierras asturianas, no sería sino una antigua cueva con culto pagano cristianizada, "la cuál uniría a su carácter de centro religioso el estar vinculada a un jefe local, de ahí el adjetivo dominica...". Sobre esta manifestación arquitectónica en la Antigüedad Tardía y Alta Edad Media hispana: Martínez Tejera 2006. Para el papel de Fructuoso en el noroeste hispano: López Quiroga 2004.
La ciudad hispana de los primeros siglos de la Antigüedad tardía dejó de ser una ciudad pagana para convertirse en una ciudad monoteista, cristiana, en la que el cultus Dei sustituyó al cultus deorum; se vivía una "efervescencia teológica" que hacía que sus habitantes cristianos participasen de forma activa en las discusiones y controversias teológicas surgidas contra priscilianistas, judíos, etc. (Arce 2005, 219) ${ }^{104}$. Con estas premisas ideológicas resultaría muy difícil justificar, ante tan acalorada feligresía, el convertir un espacio manchado con la sangre de sacrificios paganos en un espacio para la alabanza de Dios. Puede que todas estas transformaciones a las que acabamos de referirnos no necesitasen la autorización imperial pero en todos los casos tuvieron que realizarse con el consentimiento episcopal, pues solo al obispo le estaba permitido puri-

\footnotetext{
${ }^{104}$ Para un "estado de la cuestión" sobre la arquitectura cristiana hispana en la Antigüedad tardía: Martínez Tejera 2006.
} 
ficar un lugar pagano y consagrar en él una iglesia o un $\operatorname{altar}^{105}$.

En la Hispania de la tardía Antigüedad cabe hablar, para el ámbito urbano, de tan solo cuatro casos, tres de ellos al menos aun por verificar: uno es el de la "ecclesia principalis" de Tarraco, surgida quizás poco antes de $419^{106}$ sobre el espacio ocupado por el templo de Roma y Augusto, en el recinto de culto al emperador, en la "ciudad alta" o recinto superior de la ciudad (Fig. 6) ${ }^{107}$; allí se encontraban los edificios administrativos y religiosos del Concilum Provinciae Hispaniae Citerioris y el circus. El control del recinto superior de la ciudad de Tarraco estuvo durante el siglo IV en manos del poder imperial, en manos del gobernador provincial; era el ámbito de prestigio y actuación imperial que acogía los edificios de culto (Macias 2000, 263). A priori resulta difícil aceptar la posible transformación de estos templos urbanos en ecclesia, al menos hasta finales de dicha centuria, momento que coincide con un proceso de oficialización e implantación del cristianismo que provocó "una profunda transformació urbana amb el desmuntatge o la reutilizació dels antics espais de prestigi civil o religiós de caire pagà..." (Macias - Menchon - Muñoz 2005, 15). De haberse producido esta habría tenido lugar a partir del reinado de Teodosio, que fue cuando tuvo lugar la desaparición de los grandes recintos de culto imperial, incluido el de Tarraco (Macias 2000, 264 y ss). Con los datos conocidos hasta ahora es de suponer que esta transformación habría acontecido en la primera mitad del siglo VI, cuando para la construcción del episcopium "se desmontó el muro oriental del recinto de culto pagano para permitir la conexión con la sede catedralicia" ${ }^{108}$.

El segundo es el del aula/basílica localizada en el importante enclave urbano e industrial (relacionado con la producción de garum y otros productos derivados de

${ }^{105}$ Concretamente al obispo de la diócesis, en Hispania probablemente desde la celebración del I Concilio de Toledo (400), pero con total seguridad en la segunda mitad del VI: Martínez Tejera 1996.

${ }^{106}$ Pero tampoco mucho antes, siempre en el marco cronológico del siglo $\mathrm{V}$, que es cuando comenzamos a encontrar las sedes episcopales instaladas sobre los edificios del foro (al menos en Italia y Dalmacia): Marasovic 1989 y Testini - Cantino - Pani 1989, 44-45. Además, "no se dispone de evidencias que reflejen una transformación urbanística de la parte alta de la ciudad durante el siglo IV": Macias 2000, 262. Un posible ejemplo hispano podría encontrarse en Valencia, donde su primera catedral o "iglesia principal" (localizada en la actual plaza de la Almoina) se erige parcialmente sobre el solar antaño ocupado por la basílica: Ribera - Roselló 2000, 170-171.

${ }^{107}$ Una gran plaza $(153 \times 136 \mathrm{~m})$ envuelta por el temenos o muro perimetral (de $9 \mathrm{~m}$. de altura) que aguantaría la cubierta de un pórtico columnado: Macias - Menchon - Muñoz 2005, 26-29.

${ }^{108}$ Macias 2000, 267. Del mismo autor: 1999, 237. la pesca) de Troia de Setúbal (Portugal), surgido a finales del siglo I a. de C. (Maciel 1996, 193 y ss. Fig. 7, AB); y lo traemos a colación por el hecho de que según una noticia recogida por Andrés de Resende en 1593, la capilla de Nuestra Señora de Troia se erigió al parecer sobre un templo dedicado a Júpiter Amon del que todavía se conservaba, a comienzos del siglo XVIII, una cabeza de carnero realizada en mármol sobre la puerta de la primitiva capilla de Nuestra Señora de los Placeres; una noticia que será confirmada por Fray Agustín de Santa María, que en 1707 halló los restos de "hum templo gentilicio com columnas..." (Maciel 1996, 201 y 226). Desgraciadamente la Arqueología (al menos hasta el momento, pues el conjunto no ha sido excavado en su totalidad) no ha podido refrendar tales noticias y lo único que puede afirmarse con seguridad es que este edificio (así como el conocido como "baptisterium") fue parcialmente erigido sobre una antigua estructura portuaria ocupada por largos y profundos "tanques de salga" (cetariae), y que en su construcción se reutilizó sillería - que recuerda al opus quadratum del templo de la Fortuna Augustea en Pompeya - y otros materiales (columnas, basas, etc.). Incluso se llega a hablar de la amortización a principios del siglo IV de un santuario mitraico o bien de la transformación en iglesia de un aula palatina o basílica civil que entre mediados del siglo IV y principios del V fue ornamentada con una bella decoración pictórica (Maciel 1996, 225, 229 y 230-231).

El tercer caso, el del foro de la colonia Emerita Augusta (Maciel - Menchon - Muñoz 2005, 16. Arce 2005, 249), guarda aun muchas incógnitas por resolver, aunque no menos que la basílica cordobesa de San Acisclo, al parecer surgida de la transformación de un aula del palatium de Cercadilla, erigido por el tetrarca Maximiano Hercúleo (León 1996. Hidalgo 1996).

Menos dudas presenta el llamado "Templo I" ( antiguo templo de Juno?) localizado en un sector del área forense de Illici (Alcudia de Elche); sobre este edificio, un templo romano de época augustea que a su vez vendría a sustituir a un templo ibérico (Ramos 1995. Poveda 2000. Fig. 8), "se han observado reformas arquitectónicas que habría que asociar a la cristianización" de la ciudad, ya sede episcopal en la segunda década del siglo VI". Dicha transformación habría tenido lugar en el siglo VII (Poveda 2000, 91).

Sin embargo en el "campo", en el medio rural, la realidad parece mostrarse de manera distinta. Lejos de la ciudad, de la oficialidad, las creencias se personalizan y la legislación pierde efectividad; el "paganismo no oficial y personalizado" del medio rural - paradójicamente, el primero y último en ser cristianizado (Caseau 2004, 105) - es más difícil de erradicar que el urbano, sometido a una acción más directa del episcopado. Por eso la Iglesia redobla sus esfuerzos por cristianizar el campo en el siglo V.Y a estos esfuerzos se debe la sacralización y cristianización de varios templos rurales y privados en la península. 

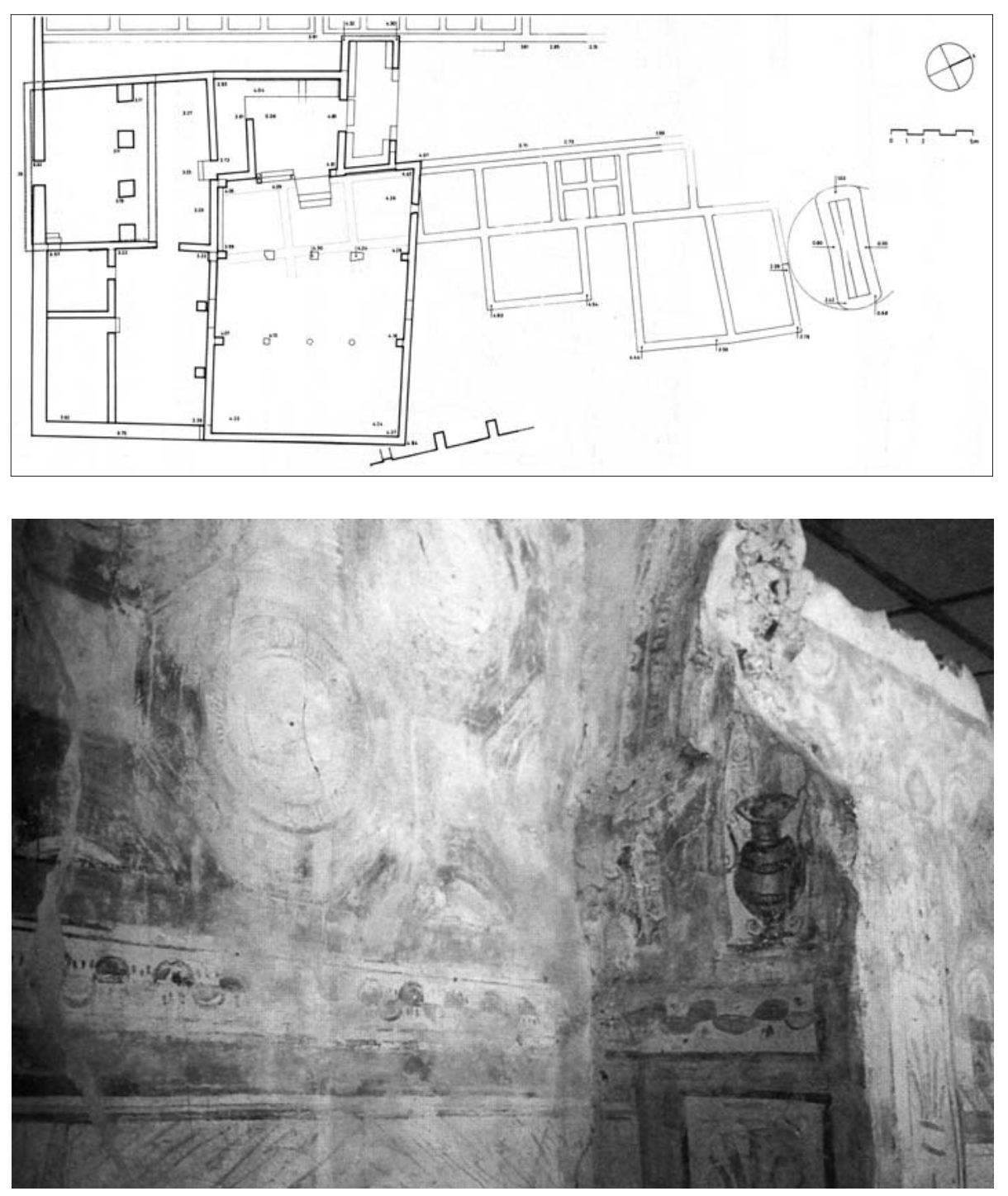

Figura 7. A-B. Complejo industrial de Troia (Setúbal, Portugal), planta de Macías (1996) y ornamentación pictórica parietal.

En la Lusitania encontraremos varios ejemplos. Uno aparece en una villa suburbana situada en las cercanías de Ossonoba: la villa de Milreu (Estoi, Portugal), de donde procede el busto del emperador Galieno, el único retrato imperial del siglo III conservado en Portugal; erigido a principios del siglo IV, el templo de la villa (y por lo tanto un templo privado), probablemente dedicado a una divinidad acuática, fue convertido en iglesia a finales del siglos IV o principios del $\mathrm{V}^{109}$ (Fig. 9, A-B). Un templo - de cella

${ }^{109}$ Una conversión que tal vez haya que relacionar con "o fausto de uma aristocracia cristá ligada ao obispo Ithacius", obispo de Ossonoba: Maciel 1996, 114, nota ${ }^{\circ} 877$. cuadrada y ábside semicircular - "cristianizado" en época teodosiana gracias a la instalación de inhumaciones a su alrededor y a la construcción de una fons o piscina bautismal de forma rectangular en la zona occidental del recinto sagrado, esta última ya en el siglo VI (Schlunk - Hauschild 1978, 111 y ss.; Fontaine 1982, 436; Hauschild 1984; Maciel 1996, 114; Brogiolo - Chavarría 2003, 19 y ss.).

Y un caso muy similar al de Milreu presenta el edificio localizado junto a la villa de Sâo Cucufate (Vidigueira, Beja, Portugal), abandonada hacia el 450 (Fig. 10, A$\mathrm{B})$; un templo privado consagrado originariamente a una divinidad pagana y construido en la segunda mitad del siglo IV que fue transformado en iglesia en una fecha que no se puede precisar, pero dentro de la primera mitad 


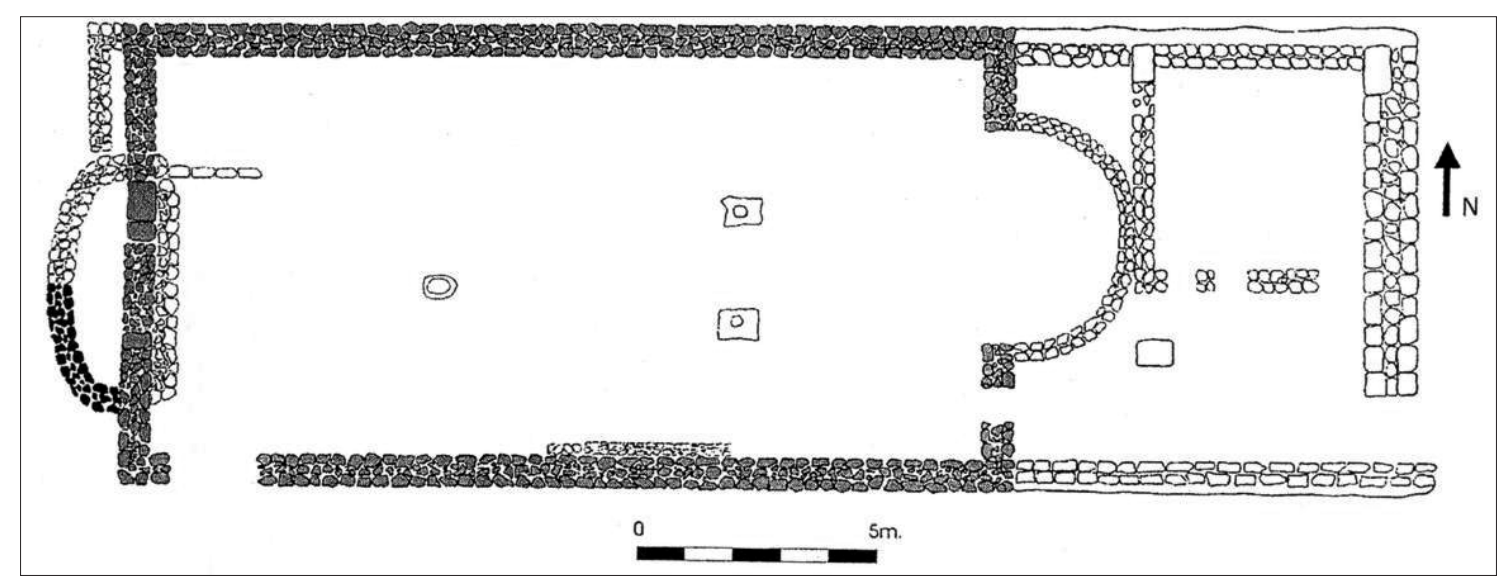

Figura 8. Basílica de Illici erigida sobre un templo de época augustea, de Poveda 2000.
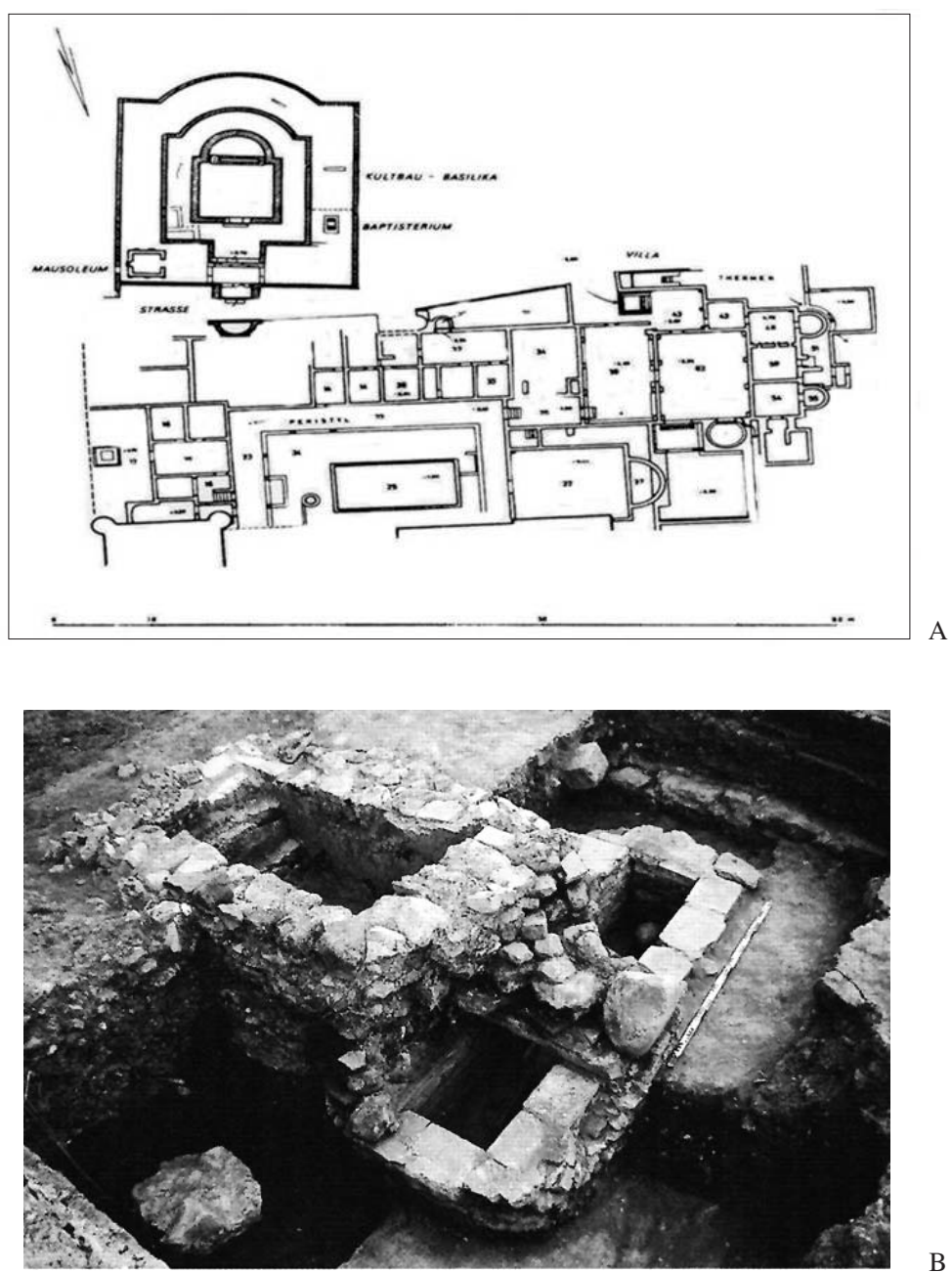

Figura 9. A-B. Villa de Milreu (Estoi, Portugal), planta de Schlunk - Hauschild 1978 y piscina bautismal. (Fotografía de los Autores). 

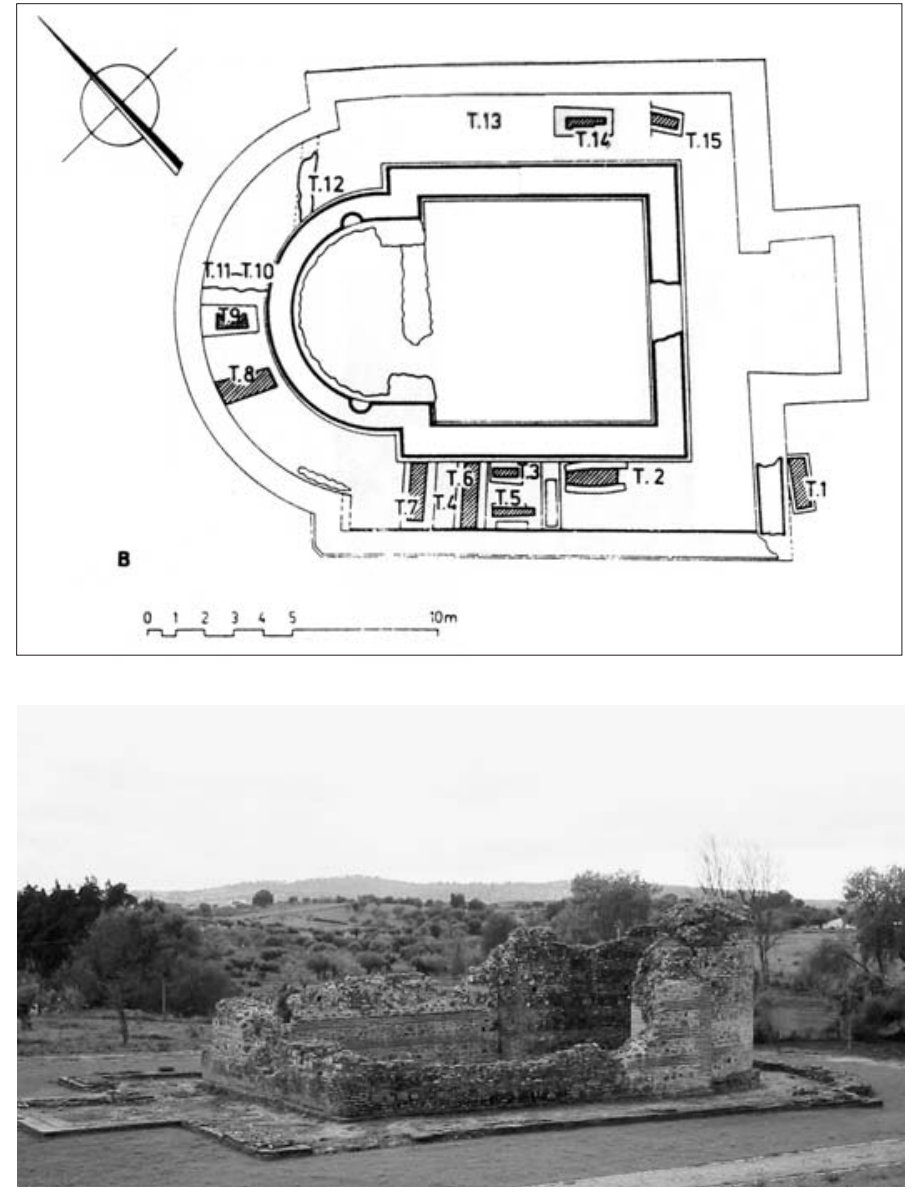

Figura 10. A-B. Villa de Sâo Cucufate (Vidigueira, Beja, Portugal), planta de Alarcâo - Étienne y Mayet 1990. (Fotografía de los autores).

del siglo V, que es cuando la presencia de sepulturas en todo el perímetro de la cella certifica con exactitud la cristianización del edificio (Alarcâo - Étienne - Mayet 1990, 126, 259 y 265 y 1995, 383. Maciel 1996, 115) ${ }^{110}$.

Fuera ya de la Lusitania, en la Gallaecia, contamos con el ejemplo de Santa Eulalia de Bóveda, en la actual provincia de Lugo (Fig. 11, A-C); se trata de un antiguo edificio subterráneo de icnografía rectangular formado por un vestíbulo dístilo "in antis" y un cuerpo principal - un posible ninfeo pagano - que habría sido transformado en edificio cultual cristiano entre los siglos IV y VI (Gómez-Moreno 1949. Fontaine 1982, 97-101) y que cuenta con una venusta pictórica interior datada en el últi-

\footnotetext{
${ }^{110}$ Según la passio del santo mártir Cucufate (elaborada en la $1^{\mathrm{a}}$ mitad o mediados del siglo VIII), escilita de origen, este fue martirizado en Barcelona hacia los años 303-304, en el reinado del emperador Máximo y el procónsul Galieno; sobre la posibilidad de que sus restos fueron sepultados en la actual localidad de Sant Cugat del Vallés (Barcelona): Riesco 1995, 153-163.
}

mo tercio del siglo IV (Schlunk 1935, 113-114; Chamoso 1952, 246-247; Núñez 1978, 131-139 y Abad 1979 y 1982, 147-152). Este singular edificio - conformado por dos edificios superpuestos - viene a confirmar "el lento tránsito del paganismo céltico en el corazón de la Gallaecia" (Fontaine 1982, 98), ya que nos encontramos ante un santuario, para algunos un ninfeo bajo-imperial, transformado en iglesia quizás a finales del siglo IV o principios del V (Gómez-Moreno 1949, Fontaine 1982, 101) ${ }^{111}$.

${ }^{111}$ En un principio (Schlunk 1935) lo consideró un mausoleo. Sobre un mausoleo privado se construyó la pequeña capi1la funeraria de San Miguel, en Odrinhas, erigida a finales del siglo IV, principios del V "sobre una casa romana de época tardía", como anexo a una villa tardía. Un edificio de acusada icnografía ultra-semicircular, dotado de un espacio rectangular con dos absidiolos, que viene a ser una "ruralización" de mausoleos de época constantiniana (como el de Santa Constanza, en Roma): Fontaine 1982, 437; Maciel inédito, 71-76 y 1996, 114. Maciel - Baracho 1994. 

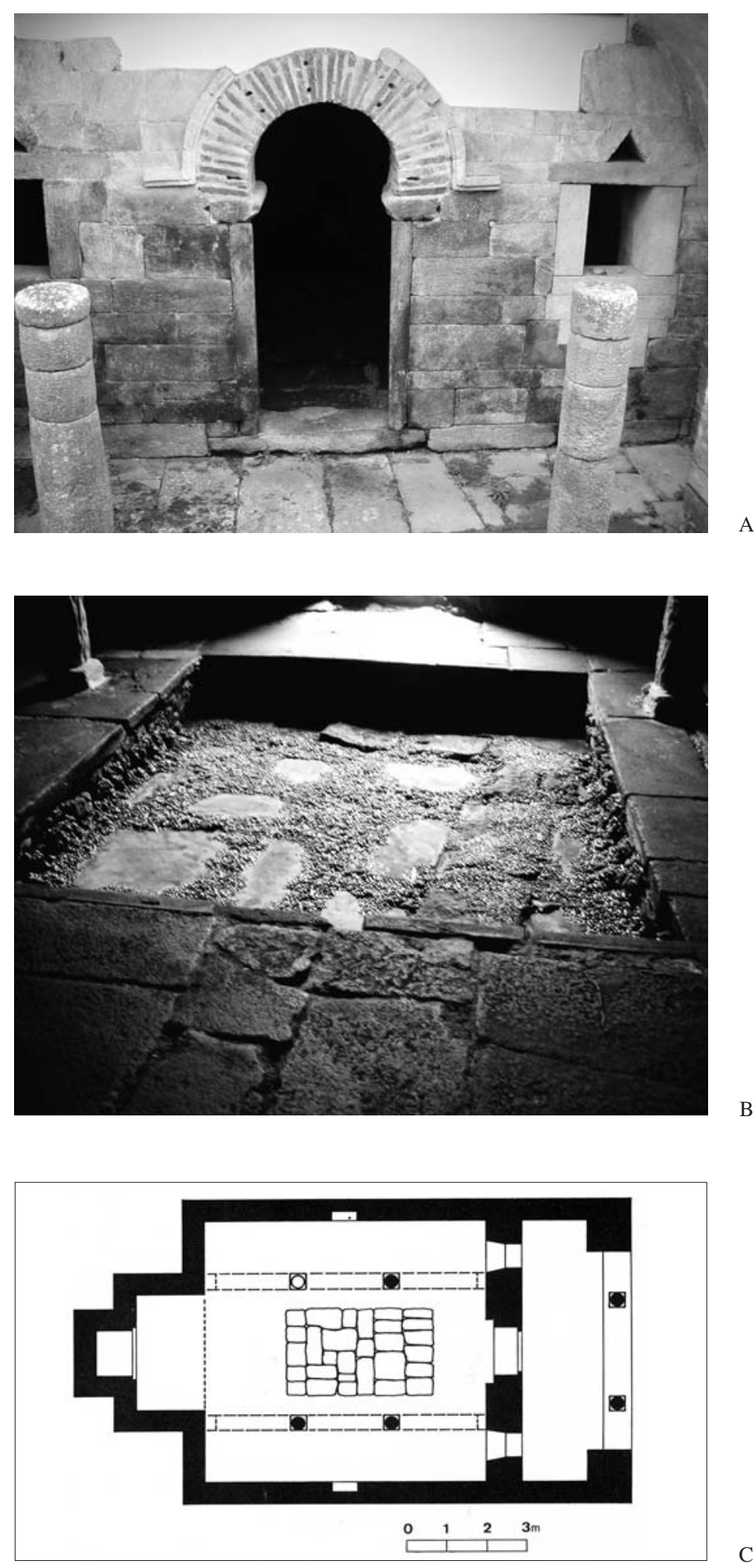

$\mathrm{C}$

Fig. 11 A-C. Santa Eulalia de Bóveda (prov. de Lugo), planta de Nuñez 1978 (Fotografías de César Abellá Vázquez). 


\section{CONCLUSIÓN}

A la hora de hacer un balance, obviamente provisional, sobre el destino de los templos paganos en Hispania durante la Antigüedad Tardía, es preciso subrayar la diferencia cuantitativa de información disponible para la Península Ibérica respecto a otras provincias occidentales y, sobre todo, orientales del Imperio. Es un proceso sobre el que los textos nos informan, como suele ocurrir con frecuencia, de forma genérica y en muchas ocasiones ambigua.

Como indicábamos al comienzo de este estudio es evidente que disponemos de escasa documentación sobre la realidad material de este proceso para el conjunto de Hispania ${ }^{112}$. Pero también es cierto que el argumento ex silentio no puede ser invocado como excusa para abordar un tema que, como bien señalaba Javier Arce, ha sido poco o nada estudiado en lo que al ámbito hispano se refiere.

Los ejemplos abordados en este trabajo, además del análisis de la información textual conservada, evidencian, en efecto, que estamos ante un proceso bastante tardío, en relación a otras áreas occidentales y orientales, en lo que respecta al desmantelamiento y destrucción de los templos paganos en Hispania. La destrucción de templos paganos para convertirlos en templos cristianos no fue un fenómeno ni mucho menos generalizado en la península. Resultó, precisamente, todo lo contrario: un proceso enormemente complejo que, además, en contadas ocasiones se llegó a producir en Hispania.

No estamos, probablemente, ante un fenómeno generalizado objeto de una acción sistemática y programada por parte de las instancias religiosas cristianas. Así parecen indicarlo, por una parte, el lento progreso de la cristianización en el medio rural y, por otra, el mantenimiento de prácticas y espacios de culto paganos tanto en el campo como en la ciudad, algo que está bien atestiguado por los textos y por la arqueología.

El progreso de la investigación arqueológica, en el marco de excavaciones ahora más atentas y rigurosas con el registro y documentación de los niveles tardo-antiguos y alto-medievales, hará envejecer pronto este estudio. Ello será para nosotros motivo de una satisfacción doble: por un lado, que se ha progresado en el conocimiento de una realidad material compleja y muchas veces esquiva; por otro, que esta prematura síntesis haya sido al menos, aún en su premura, de cierta utilidad.

${ }^{112} \mathrm{Y}$ por tanto pensamos que ya no se puede afirmar que sea una norma, en la estratigrafía arqueológica de los centros de culto cristianos, la presencia o existencia de un templo pagano previo: Sanz Serrano 1995, 243. No obstante, será la Arqueología, en última instancia, quien tenga la última palabra al respecto.

\section{BIBLIOGRAFÍA}

ABAD CASAL, L. (1979): "Aportación al estudio de Santa Eulalia de Bóveda", in: Actas del XV Congreso Nacional de Arqueología, Zaragoza.

ABAD CASAL, L. (1982): Pintura romana en España, 2 Tomos, Universidad de Alicante-Universidad de Sevilla.

ALARCÂO, J, ÉTIENNE, R. y MAYET, F. (1990): Les villas romaines de $S$. Cucufate (Portugal), París.

ALARCÂO, J, ÉTIENNE, R. y MAYET, F. (1995): "Os Monumentos cristâos da villa de S. Cucufate", in: Actas de la IV ${ }^{a}$ Reunió d'Arqueologia Cristiana Hispànica, (Lisboa) Barcelona, 383-387.

ALFÖLDY, A. (1969): The Conversion of Constantine and Pagan Rome, Oxford.

ALMEIDA, F. de (1958): "Iscriçôes paleocristâs do Museo Arqueológico de S. Miguel de Odrinhas", Comunicaçôes dos Serviços Geológicos de Portugal, T. 39, 27-36.

ALMEIDA, F. de, (1962): "Arte visigótica em Portugal", O Arqueólogo portugués, Nova Serie 4, Lisboa.

ARCE, J. (1971): "Conflictos entre Paganismo y Cristianismo en Hispania durante el siglo IV", Príncipe de Viana, 245-255.

ARCE, J. (1975): "Reconstrucciones de templos paganos en época del emperador Juliano (361-363 d. C)", Revista Storica dell'antichità V, 201-215.

ARCE, J. (2003: Mérida Tardorromana, 300-580 A. D., Mérida.

ARCE, J. (2005): Bárbaros y romanos en Hispania (400-507 A. D.), Madrid.

AUGIER, Y. (1999): "Le financement de la construction et de l'embellisement des sanctuaries de Syrie du Sud et d'Arabie aux époques hellénistiques et romaines", Topoi 9/2, 741-776.

BAKER, J. (1994): Living and Working with the Gods. Studies of Evidence of Private Religion and its Material Environment in the City of Ostia (100-500 A.D.), Amsterdam.

BARNES, D. (1984): "Constantine`s Prohibition of Pagan Sacrifice", American Journal of Philology 105/1, 69-72.

BARNES, D. (1989): "Christians and Pagans in the Reing of Constantinus", in: L'Église et l'Empire au IV $V^{e}$ siècle, Ginebra, 325-327.

BARRAL I ALTET, X. (1982): "Transformacions de la topografía urbana a la Hispania cristiana durant l'antiguitat tardana", in: Actas de la II ${ }^{a}$ Reunió d'Arqueologia Paleocristiana Hispànica, Barcelona, 105-132.

BEATRICE, P.F. (1996): "La christianisation des campagnes pendant l'Antiquité tardive dans les régions méditerranéennes. Bilan des recherches et questions de méthode", in: J.P. Massaut y M.E 
Hennau (ed.), La christianisation des campagnes (Actes du Colloque du C.I.H.E.C), 9- 35, Bruselas.

BLOCH, H. (1945): "A new document of the Last Pagan Revival in the West, 393-394, A.D.", Harvard Theological Review 38, 199-244.

BONAMONTE, G. G. (1992): "Sulla confisca dei beni mobili dei templi in epoca costantiniana", Costantino il Grande, Vol. I, 171-201, Macerata.

BROGIOLO, G. P. - CHAVARRÍA, A. (2003): "Chiese e insediamenti tra V e VI secolo: Italia Settentrionale, Gallia Meridionale e Hispania", in: G. P. BROGIOLO (ed.), Chiese e insedimenti nelle campagne tra V e VI secolo, Mantua, 7-38.

BROWN, P. (1978): The Making of Late Antiquity, Harvard.

BUENACASA PÉREZ, C. (1997): "La figura del Obispo y la formación del patrimonio de las comunidades cristianas según la legislación imperial de Teodosio I (379-395)", Studia Ephemeridis Augustinianum 58, I, 121-139.

BUENACASA PÉREZ, C. (1997-1998): "La decadencia y cristianización de los templos paganos a lo largo de la Antigüedad Tardía (313-423)", Polis n ${ }^{\circ}$, 25-50.

CAILLET, J. P. (1996): "La transformation en églises d'edifices publiques et des temples à la fin de l'Antiquité", in: Cl. Lepelly (ed.), La fin de la cité antique et le début de la cité mediévale de la fin du III siècle à l'avénement de Charlemagne, Bari, 191211.

CABALLERO ZOREDA, L. (2003): "Iglesia de Santa Lucía del Trampal", in: P. Mateos y L. Caballero (Eds.), Repertorio de arquitectura cristiana en Extremadura, 15-20 (Anejos de Archivo Español de Arqueología XXIX), Mérida.

CABALLERO ZOREDA, L. y SANCHEZ SANTOS, J. (1990): "Reutilizaciones de material romano en edificios de culto cristiano", in: Cristianismo y aculturación en tiempos del Imperio Romano (Antigüedad y Cristianismo VII), Murcia, 431-486.

CALLOT, O. (1997): "La christianisation des sanctuaires romains de la Syrie du Nord", Topoi n ${ }^{\circ}$ 7, 735-750.

CARRILLO, J. R.- HIDALGO, R.- MURILLO, J. F. VENTURA, A. (1999): "Córdoba. De los Orígenes a la Antigüedad Tardía”, in: F. García Verdugo y F. Acosta (eds.), Córdoba en la Historia, la construcción de la Urbe, Córdoba, 37-74.

CASEAU, B. (2001): "La desacralización des espaces et des objets religieux païens durant l'Antiquité Tardive", in: KAPLAN, M (dir.), Le sacré et son inscription dans l'espace à Byzane et en Occident, Études Comparées, París, 61-123.

CASEAU, B. (2004): "The fate of rural temples in Late Antiquity and the Christianisation of the countryside", in: W. Bowden, L. Lavan and C. Machado (Eds.),
Recent Research on the Late Antiquity Countryside (Late Antiquity Archaeology, vol. 2), Leiden-Boston , 105-144.

CHAMOSO LAMAS, M. (1952): "Sobre el origen del monumento soterrado de Santa Eulalia de Bóveda (Lugo)", Cuadernos de Estudios Gallegos VII, $\mathrm{n}^{\circ}$ 22, 231-251.

CHASTAGNOL, A. (1986): "La législation sur les biens des villes au IV siècle à la lumière d'une inscription d'Éphese", in: Atti dell'Accademia Romanistica Costantiniana 6, Perugia, 77-104.

DE CAZANOVE, O. (2000): "Les lieux de culte italique. Approcher romaines, désignations indigénes", in: VAUCHEZ, A (ed.), Lieux sacrés, lieux de culte, sanctuaries. Approches terminologiques, methodologiques, historiques et monographiques, Roma, 31-41.

DEICHMANN, F. W. (1939): "Früchristliche Kirchen in antiken Heiligtümen", Jahrbuch de Deutsches Archaeologisches Institut 54, 10-136.

DEICHMANN, F. W. (1954): "Christianisierung, II (der Monumente)", Reallexikon für Antike und Christentum II, Stuttgard, 1228-1241.

DEICHMANN, F. W. (1964): "Vom Tempel zur Kirche", Mullus. Festschrift Theododr Klauser, Munich, 52-59.

DUPONT, Cl. (1979): “La politique de Julián à l'égard du christianisme dans les sources littéraires des $\mathrm{IV}^{\mathrm{s}}$ et $\mathrm{V}^{\mathrm{s}}$ siècles après Jésus-Christ", in: Atti dell'Accademia Romanistica Costantiniana 3, 233-235.

DUVAL, N. (1973): "Église et temple en Afrique du Nord. Notes sur les installations chrétiennes dans les temples à cour", Bulletin archéologique. Comité des travaux historiques et scientifiques 7, 265296.

JUAN, E. - LERMA, J. V. (2000): "La villa aúlica del 'Pla del Nadal' (Riba-Roja de Túria)", in: RIBERA I LACOMBA (Coord.), Los orígenes del Cristianismo en Valencia y su entorno, Valencia, 135-142.

ESCRIBANO PAÑO, M ${ }^{\mathrm{a}}$ V. (1977): "Acción política, económica y social de la iglesia hispana durante el siglo V", Hispania Antiqua VII, 63-78.

ESPINOSA, U. (1997): "La ciudad en el valle del Ebro durante la Antigüedad Tardía", VII Semana de Estudios Medievales (Nájera) Logroño, 37-59.

FALCHI, G. L. (1986): "Legislazione e politica ecclesiastica nell'Imperio romano dal 380 d. C. al Codice Teodosiano", in: Atti dell'Accademia Romanistica Costantiniana 6, 179-212.

FERNÁNDEZ, G. (1981): "Destrucciones de templos en la Antigüedad Tardía", Archivo Español de Arqueología 54, 141-156.

FLICHE, A. y MARTIN, V. (1948): Histoire de l'Église depuis les origines jusqu'à nos tours, T. IV, 19-20, París. 
FONTAINE, J. (1982): El Prerrománico (Vol. 8 de la serie "La España Románica"), Madrid.

FOSCHIA, L. (2000-2002) : "La reutilization des sanctuaries païens par les Chrétienes Grèce continentale (IVe-VIIe s.)", Revue des Études grecques $113,413-434$.

FOWDEN, G. (1978): "Bishops and Temples en the Eastern Roman Empire", Journal of Theological Studies 29, 53-78.

FRANTZ, A. (1965): "From Paganism to Christianity in the Temples of Athenas", Dumbarton Oaks Papers 19, 187-205.

FERNÁNDEZ OCHOA, C. ZARZALEJOS PRIETO, M. (2001): "Las termas públicas de las ciudades hispanas en el Bajo Imperio", in: Complutum y las ciudades hispana en la Antigüedad Tardía, Alcalá de Henares, 19-35.

FERNÁNDEZ OCHOA, C., MORILLO CERDÁN, A. y LÓPEZ QUIROGA, J., (2005): "La dinámica urbana de las ciudades de la fachada noratlántica y del cuadrante noroeste de Hispania durante el Bajo Imperio y la Antigüedad tardía (siglos III-VII d.C.)", in: VI Reunió d'Arqueologia Cristiana Hispanica (Valencia, 2003), Barcelona, 95-119.

FUENTES, Á. (1999): "La ciudad en la antigüedad tardía a la luz de los textos arqueológicos", in: Complutum y las ciudades hispana en la Antigüedad Tardía, Alcalá de Henares, 73-86.

FUENTES, Á. (2000): "Las termas en la Antigüedad Tardía: reconversión, amortización, desaparición. El caso hispano", in: Actas del Coloquio Internacional Termas romanas en el Occidente del Imperio, Gijón, 135-145.

GARCÍA MORENO, L. (1977-1978): "La cristianización de la topografía de las ciudades de la Península Ibérica durante la Antiguiedad Tardía", Archivo Español de Arqueología $\mathrm{n}^{\circ}$ 50-51, 311-321.

GARCÍA MORENO, L. (1988): "Problemática de la iglesia hispánica durante la supremacía ostrogoda (507-549)", Hispania Cristiana (Estudios en honor del Prof. José Orlandis), Pamplona, 147-160.

GARCÍA MORENO, L. (1990): "Elite e Iglesia hispanas en la transición del Imperio Romano al Reino Visigodo", in: La Conversión de Roma. Cristianismo y Paganismo, Madrid, 223-259

GAUDEMET, J. (194)7: "La législation religieuse de Costantin", Revue d'Histoire de l'Église de France 33, 25-61.

GAUDEMET, J. (1981): "Les relations entre le pouvoir politique et les communautés chrétiennes d'après le Code Théodosien", in: Atti dell'Accademia Romanistica Costantiniana 4, 431-446.

GÓMEZ-MORENO MARTÍNEZ, M. (1949): "Santa Eulalia de Bóveda" (reimpreso en Miscellanea, primera serie), Madrid, 414-434.
GROSSE, R. (1947): Las fuentes de la época visigoda $y$ bizantinas (Fontes Hispaniae Antiquae IX), Barcelona.

GUERRA, A, CHATTNER, Th. FABIÂO, C. y ALMEIDA R. (2003): "Novas investigações no santuário de Endovélico (S. Miguel da Mota, Alandroal): a campanha de 2002", Revista Portuguesa de Arqueología Vol. 6, nº 2, 415-479.

GURT I ESPARRAGUERA, J. M. (1995): “Topografía cristiana de Lusitania. Testimonios arqueológicos", in: A. Velázquez, E. Cerrillo y P. Mateos (eds.), Los últimos romanos en Lusitania, Mérida, 73-95.

GURT I ESPARRAGUERA, J. M. (2000-2001): "Transformaciones en el tejido de las ciudades hispanas durante la Antigüedad Tardía: dinámicas urbanas", Zephyrus nos 53-54, 443-471.

GURT I ESPARRAGUERA, J. M. (2004): "La Catalogne durant l'Antiquité tardive. Les transformations du paisaje urbain d'après l'achèologie", in: M. Fixot (dir.), Paul-Albert Février de l'Antiquité au Moyen Âge, 215-235 (Fréjus), Aix-en-Provence.

GURT, J. M., RIPOLL, G. y GODOY, C. (1994): "Topografía de la Antigüedad Tardía hispánica. Reflexiones para una propuesta de trabajo", Antiquité Tardive 2, 161-180.

HANSON, R. P. C. (1978): "The Transformation of Pagan Temples into Churches in the Early Christian Centuries", Journal of Semitic Studies 23, 257267.

HAUSCHILD, Th. (1984): "A villa romana de Milreu, Estói, Algarve", Arqueología no 9, 94-104.

HIDALGO PRIETO, R. (1996): "Análisis arquitectónico del complejo monumental de Cercadilla (Córdoba)", in: Colonia Patricia Corduba. Una reflexión arqueológica, 235-248, Córdoba.

JANIN, R. (1953): La Géographie ecclésiastique de l'empire bizantin I, París.

JIMÉNEZ SÁNCHEZ, J. A. y SALES CARBONELL, J. (2004): "Termas e Iglesias durante la Antigüedad Tardía: ¿reutilización arquitectónica o conflicto religioso? Algunos ejemplos hispanos", in: Antigüedad y Cristianismo XXI (Sacralidad y Arqueología. Homenaje al Prof. Thilo Ulbert al cumplir 65 años), Murcia, 185-201.

JOANNOU, P.-P. (1972): La législation impériale et la christianisation de l'Empire Romaní (311-476), Roma.

KEAY, S. (1996): "Tarraco in Late Antiquity", in: Christie, N., y Loseby, S. (eds.), Town in Transition. Urban evolution in Late Antiquity and the Early Middle Ages, Aldershot, 18-44.

KLEIN, R. (1995): "Distruzioni di temple nella tarda antichità. Un problema politico, culturale e sociale", in: Atti dell'Accademia Romanistica Costantiniana 10, 127-152. 
KRAUTHEIMER, R. (1980): Rome. Profile of a City, 312-1308 (Princeton University Press), Princeton.

KUNDEREWICZ, C. (1971): "La protection des monuments d'architecture antique dans le code Théodosian", Studi in onore di Edoardo Volterra, T. IV, Milán, 137-153.

LEÓN, P. (1996): "Hacia una nueva visión de la Córdoba romana", in: Colonia Patricia Corduba. Una reflexión arqueológica, 17-35, Córdoba.

LEPELLEY, CL., (1979): Les cités de l'Afrique romaine au Bas-Empire I, París.

LEWIS, M. J. T. (1966): Temples in Roman Britain, Cambridge.

LÓPEZ QUIROGA, J. (2004a): El final de la Antigüedad en la Gallaecia: la transformación de las estructuras de poblamiento entre Miño y Duero (siglos $V$-X) (Fundación Pedro Barrié de La MazaSerie 'Galicia Histórica'. Instituto de Estudios Gallegos 'Padre Sarmiento'-CSIC), A Coruña.

LÓPEZ QUIROGA, J. (2005): "Los orígenes de la parroquia rural en el occidente de Hispania (siglos IV-IX) (Provincias de Gallaecia et Lusitania), in: Ch. Delaplace (dir.), Aux origines de la paroisse rurale en Gaule méridionale (IVe-IXe siècles) (ed. Errance), París, 193-229.

LÓPEZ QUIROGA, J. y RODRÍGUEZ LOVELLE, M. (1992), "Aux origines monastiques de la Galice interièure (Ve-Xe s.)", Histoire Médiévale et Archéologie 5, 265-271.

LÓPEZ QUIROGA, J. y RODRÍGUEZ LOVELLE, M. (1996): "Reflexiones sobre la evolución de la organización territorial diocesana y parroquial en el Norte de Portugal", Revista Portuguesa de História $31,19-63$

LÓPEZ QUIROGA, J. y RODRÍGUEZ LOVELLE, M. (e. p.): La dinámica del poblamiento en Galicia durante la Antigüedad Tardía y la Alta Edad Media (BAR International Series), Oxford.

LÓPEZ QUIROGA, J. y RODRÍGUEZ MARTÍN, F. G. (2000-01): "El 'final' de las villae en Hispania (ss. V-VIII d. C.): I. La pars urbana de las villae y sus transformaciones", Portugalia XXI-XXII, 17-190.

LORING GARCÍA, M.I (1986-1987): "La difusión del cristianismo en los medios rurales de la Península Ibérica a fines del Imperio Romano", Studia Historica IV-V, 194 y ss.

MACIAS SOLÉ, J. M. (1999): La ceràmica comuna tardoantigua a Tarraco (TULCIS Monografías Tarraconenses, 1, Museo Nacional Arqueológico de Tarragona), Tarragona.

MACIAS SOLÉ, J. M. (2000): “Tarraco en la Antigüedad Tardía: un proceso simultáneo de transformación urbana e ideológica", in: Los orígenes del Cristianismo en Valencia y su entorno, Valencia, 259-271.
MACIAS SOLÉ, J. M., MENCHON I BES, J. y MUÑOZ MELGAR, A. (2005): Tàrraco: Guia arqueològica visual. Reconstrucciò virtual de l'urbs $i$ els seus voltants, Digivisión, Tarragona.

MACIEL, M. J. (1980): O "De correctione rusticorum" de S. Martinho de Dume, Braga.

MACIEL, M. J. (1983): Sâo Miguel de Odrinhas (Sintra): Arquitectura romana ou paleocristâ? (Dissertaçâo dactilografada de Maestrado em História da Arte, Universidade Nova de Lisboa), Lisboa.

MACIEL, M. J. (1996): Antiguedade Tardia $e$ Paleocristianismo em Portugal, Lisboa.

MACIEL, M. JUSTINO y BARACHO, C (1988) 1994: "O Monumento Absidal de Odrinhas (Sintras)", Actas de la III ${ }^{a}$ Reunió d'Arqueologia Cristiana Hispànica, Barcelona, 93-103.

MACMULLEN, R., (1984): Christianising the Roman Empire (100-400), New Haven.

MÂLE, É. (1950): La fin du paganismo en Gaule et les plus anciennes basiliques chrétiennes, París.

MANGO, C. (1994): "L'attitude byzantine à l'égard des antiquités gréco-romaines", Byzance et les images, París, 95-120.

MARASOVIC, T (1986) 1989: "Ristrutturazione delle cità sulla costa orientale adriatica nell'epoca paleocristiana”, in: XI Congrés Internationale d'Archéologie Chrétienne T. I, Roma, 327-344.

MARFIL RUIZ, P. (2000): "Córdoba de Teodosio a Abd al-Rahman III", in: Visigodos y Omeyas. Un debate entre la Tardoantigüedad y la Alta Edad Media (Anejos de Archivo Español de Arqueología XXIII) Madrid, 117-141.

MARTÍNEZ TEJERA, A. M. (1993): "De nuevo sobre áreas ceremoniales y espacios arquitectónicos intermedios en los edificios hispanos (ss. IV-X): atrio y pórtico", Boletín de Arqueología Medieval Vol. 7, pp. 163-215, Madrid.

MARTÍNEZ TEJERA, A. M. (1996): "Dedicaciones, consagraciones y Monumenta consecrationis (siglos VI-XII): testimonios epigráficos altomedievales en los antiguos reinos de Asturias y León”, Brigecio 6, 77-102.

MARTÍNEZ TEJERA, A. M. (2005): "Reflexiones en torno a la edilicia cristiana en la tardo-antigüedad hispana (ss. IV-VII) (I)", in: Galia e Hispania en el contexto de la presencia 'germánica' (ss. VVII): Balance y perspectivas, (Madrid - Alcalá de Henares).

MARTÍNEZ TEJERA, A. M. (2006): "La realidad material de los monasterios y cenobios rupestres hispanos (siglos V-X)", in: Actas del XIX Seminario sobre Historia del Monacato "Monjes y monasterios hispanos en la Alta Edad Media" (Aguilar de Campoo 2005), Palencia. 
MARTÍNEZ TEJERA, A. M. (2004) inédito: Arquitectura monástica en tiempos de San Genadio (;865?935/937): San Miguel de Escalada y Santiago de Peñalba (prov. de León), dirigida por el Dr. D. Isidro Gonzalo Bango Torviso, Catedrático de Arte Antiguo y Medieval, Dpto. de Historia y Teoría del Arte, Universidad Autónoma de Madrid (30 de septiembre de 2004)

MATEOS CRUZ, P. y ALBA CALZADO, M. 2000: "De Emerita Augusta a Marida", Visigodos y Omeyas. Un debate entre la Tardoantigüedad y la Alta Edad Media (Anejos de Archivo Español de Arqueología XXIII), Madrid, 117-141.

MILOJEVIC, M (1996): "Forming and Transforming Proto-Byzantine urban public space", in: P. ALEN y JEFFREYS, E (Eds.), The sixth century. End or Beginning? (Byzantina Australiesia 10), Brisbane, 247-262.

MURGA, J. L (1979): "El expolio y deterioro de los edificios públicos en la legislación post-constantiniana", in: Atti dell'Accademia Romanistica Costantiniana 3, 239-263.

NOLLA I BRUFAU, J. M (2000): "El obispado emporitano", en Los orígenes del Cristianismo en Valencia y su entorno, Valencia, 243-249.

NOLLA, J. M., SAGRERA, J., PALAHÍ, Ll. y VIVÓ, D. (1995): Ciuitatis Impuritanae Coementeria. Les necròpolis de la Neàpolis, (Estudi General, Revista de la Facultat de Lletres de la Universitat de Girona, $\left.n^{\circ} 15\right)$, Girona.

NÚÑEZ RODRÍGUEZ, M. (1978): Arquitectura Prerrománica, Historia da Arquitectura Galega, (Colegio Oficial de Arquitectos de Galicia), Madrid.

Obras completas de Martín de Braga (edición y traducción realizada por Ursicino Domínguez del Val, Fundación Universitaria Española) Madrid, 1990.

ORLANDIS, J. (1991): La vida en España en tiempos de los Godos, Madrid.

ORR, D. (1978): "Roman domestic religion: the evidence of the household shrines", Aufstieg und Niedergang der Römischen Welt 16.2, 1157-1591.

PALOL I SALELLAS, P. de., (1953): Tarraco hispanovisigoda, Tarragona.

PASCUAL PACHECO et alii (1997): "València i el seu territori: contexts ceràmics de la fi de la romanitat a la fi del califat (270-1031)", in: Contextos ceràmics d'època romana tardana $i$ de l'alta edad mitjana (segles IV-X) (Arqueo Mediterrània n $\left.{ }^{\circ} 2\right), 179-202$.

PENSABENE, P. (2004): "Reimpiego e depositi di marmi a Roma e Ostia tra la seconda metà del IV a i primi decenni del V secolo", in: Michel FIXOT (dir.), Paul-Albert Février de l'Antiquité au Moyen Âge, Fréjus, 281-297.

PERCIVAL, J. (1976): The Roman Villa, Londres.

PEREIRA, G. (1889): "O Santuário de Endovellico", Revista Archeológica 3, 145-149.
PIGANIOL, A. (1932): L'empereurer Constantin, París. POVEDA NAVARRO, A. M. (2000): "El obispado de Ilici”, in: Los orígenes del Cristianismo en Valencia y su entorno, Valencia, 85-92.

RAMOS FERNÁNDEZ, R., (1995): "Un templo romano de época augustea en La Alcudia de Elche", in: Actas del XXII Congreso Nacional de Arqueología, T. I, Vigo, 349-353.

RAMOS-LISSON, D. (2005): "El concilio de Elvira en la historiografía moderna", en Manuel Sotomayor y José Fernández Ubiña (Coords.) El Concilio de Elvira y su tiempo, Universidad de Granada, $65-88$.

RASCÓN MARQUÉS, S. y SÁNCHEZ MÓNTES, A. L. (2000): "Complutum. Tradición y cambio en la Antigüedad Tardía", in: Los orígenes del Cristianismo en Valencia y su entorno, Valencia, 235-242.

RIBERA I LACOMBA, A. (2000): "Valentia siglos IV y V: el final de una ciudad romana", in: Los orígenes del Cristianismo en Valencia y su entorno, Valencia, 19-32.

RIBERA I LACOMBA, A. y ROSSELLÓ MESQUIDA, M. (1999): L'Almoina: el nacimiento de la Valentia cristiana, Quaderns de Difusiò Arqueológica $n^{\circ} 5$, Valencia.

RIBERA I LACOMBA, A. (2000): "La ciudad de Valencia en época visigoda", in: Los orígenes del Cristianismo en Valencia y su entorno, Valencia, 151-164.

RIESCO CHUECA, P., 1995: Pasionario Hispánico (siglos VII-XI), Sevilla.

ROSSELLÓ MESQUIDA, M. (1995): "Punta de l'Illa de Cullera (Valencia): Un posible establecimiento monástico del siglo VI", in: Actas de la IV Reunión de Arqueología Cristiana Hispánica, Barcelona, 151-161.

ROSELLÓ MESQUIDA, M. (2000): "El recinto fortificado de "València la Vella" en Riba-Roja de Túria", in: Los orígenes del Cristianismo en Valencia y su entorno, Valencia, 127-133.

SALZMAN, M.R., (1987): "Superstitio in the Codex Theodosianus and the Persecution of Pagans", Virginia Center for Housing Research 41, 172-188.

SÁNCHEZ RAMOS, I. (2002): "La incidencia del Cristianismo en el mundo funerario romano cordubense", in: Vaquerizo, D. (ed.), Actas del Congreso Internacional "Espacio y usos funerarios en el Occidente romano”, vol. 2, Córdoba, 325-342.

SANZ SERRANO, R. (1995): "Hacia un nuevo planteamiento del conflicto paganismo-cristianismo en la Península Ibérica", Ilu 0, 237-248.

SANZ SERRANO, R. (1998): "La destrucción de centros de culto paganos como forma de persecución religiosa en la Península Ibérica”, Hom. a J. M. Blázquez, VI, Madrid, 247-263. 
SANZ SERRANO, R. (2003): Paganos, adivinos y magos: análisis del cambio religioso en la Hispania Tardoantigua, Gerión, Anejo Vol. 21, nº 7, 1-189

SARADI-MENDELORICI, H., (1990): "Christian Attitudes towards Pagan Monuments in Late Antiquity and Their legacy in Later Bizantine Centuries", Dumbarton Oaks Papers 44, 47-61.

SCHLUNK, H. (1935): "Santa Eulalia de Bóveda", in: Das siebente Jahrzehnt, (Goldschmidt Festschrift zum 70), Berlín, 1-13.

SCHLUNK, H. y HAUSCHILD, Th. (1978): Die Denkmäler der frühchristlichen und westgotischen zeit. Hispania Antiqua, Verlag Philipp von ZabernMainz um Rhein.

SPIESER J.M., (1976): "La christianisation des sanctuaires païens en Grèce", in: U. JANTZEN (ed.), Neue Forschungen in griechischen Heiligtümern, (Olimpia) Tubingia, 309-320.

SOTOMAYOR y MURO, M. (1981): "Cristianismo primitivo y paganismo romano en Hispania", Memorias de Historia Antigua 5, 173-185.

SPIESER, J.-M (1976): "La christianisation des sanctuaries païens en Grèce", in: U. Jantzen (Ed.), Neue Forschungen in griechischen Heiligtümern, Tübingen, 309-320.

STANCLIFFE, C. (1983): Saint Martin and his Hagiographer: History and Miracle in Sulspicius Severus, Oxford.

SULPICE SÉVÉRE: Vie de Saint Martin ( ed. de J. Fontaine, Sources Chrètiennes $\mathrm{n}^{\mathrm{os}}$ 133-135, París 1968-1969)

TED'A (Taller-Escola d`Archeología) (1990): L'anfiteatre romá de Tarragona, la basílica visigòtica i l'església romànica, Tarragona.

TESTA, E. (1991): "Legislazione contro il paganesimoi e cristianizzazione dei templi (sec. IV-VI)", Liber Annus 41, 311-326.

TESTINI, P., CANTINO, G. y PANI, L (1989): "La cattedrale in Italia”, in: XI Congrés Internationale d'Archéologie Chrétienne T. I, Roma, 5-232.
THÉLAMON, Fr., (1990): "Destruction du paganisme et construction du Royaume de Dieu d'après Rufin et Augustin", in: Cristianesimo nella storia Ricerche storiche esegetiche teologiche Anno XI, 3 (L'intolleranza cristiana nei confronti dei pagani, a cura di Pier Ferdinando Beatrice), Bolonia, 523544

TROMBLEY, F.R. (1995): Hellenic Religion and Christianization (370-519), 2 Vols., Leiden.

Vida de Constantino, de Eusebio de Cesarea (Introducción, tradución y notas de Martín Gurruchaga, Biblioteca Clásica Gredos no 190), Madrid, 1994.

TSAFRIR, Y. (1998): "The Fate of Pagan Cult Places in Palestine: The Archaeological Evidence with emphasis on Beth Shean", in: H. LAPIN (ed.), Religious and Ethnic Communities in Later Roman Palestine (Studies and Texts in Jewish History and Culture, 5), Bethesda, 197-218.

VAES, J. (1989): “'Nova construere sed amplius vetusta servare': la reutilisation chrétienne d'edifices anticues (en Italia)", in: Actes $d u$ XI congrès internacional d'archéologie chrétienne, T. I, Roma, 299-321.

VELASCO, Á. (2000): "El obispado de Saetabis", in: Los orígenes del Cristianismo en Valencia y su entorno, Valencia, 77 y ss.

VRIEZEN, K.J.H. (1995): "Churches built over Pagan Sanctuaries: a frequent phenomenon in Byzantine Palaestina/Arabia", in: P.W Van Der Horst (Ed.), Churches, Temples and Theatres, Aspects of Religious Contact and Conflict in the Ancient World, Utrech, 69-79.

WARD-PERKINS, B. (2003): "Reconfiguring Sacred Space: from Pagan Shrines to Christian Churches", in: G. Brands und H-G. Severin (Eds.), Die spätantike Stadt und ihre Christiniaserung, Wiesbaden, 285-290.

Recibido el 12-04-2006 Aceptado el 10-09-2006 
